\title{
Assessment of Intra-trade Intensity within Common Market for Eastern and Southern Africa.
}

\author{
Tolessa Shanko Kerore $(\mathrm{PhD})$ \\ tolejiruun@gmail.com
}

Pan African University, Institute of Governance, Humanities and Social Sciences, Cameroon, Yaoundé

\begin{abstract}
Utilizing panel data, this study looked at the intra-trade intensity within the Common Market for Eastern and Southern Africa (COMESA) region from 2000 to 2016, with a particular focus on export trade. To quantify the intensification of trade among member states, the study employed the trade intensity index. The results of the Trade Intensity Index (TII) show that, while intra-COMESA trade remains low for the majority of members, the intensity result appears to be increasing at a modest rate at the regional level. According to the study, the regional trade strength of intra-COMESA exports climbed from $11 \%$ in 2000 to 13.6 percent in 2016. Egypt and Kenya, in particular, have increased their export trade among COMESA members, whereas Libya has the smallest export trade share, followed by Eretria. To expand bilateral trade among member states, it is recommended that COMESA members invest in complementary products (export diversification) where they have a comparative advantage by identifying priority products in the region, improving economic size, implementing the AU's 2012 declaration of Continental Free Trade Area (CFTA), developing regional transport infrastructure, and strengthening institutional democracy.
\end{abstract}

Key words: Trade Integration, COMESA, Trade Intensity, Export, Import

\subsection{Background to the study}

Economic integration across countries and regions has long been regarded as a necessary component of economic growth and development. Regional integration initiatives began shortly after most African countries gained independence, and a number of Regional Trade Agreements (RTAs) were signed to support their economic growth and development. The performance of trade agreements among African regions, on the other hand, has not been as planned. According to the Economic Commission for Africa (ECA) (2012), the condition of intra-African commerce is discouraging, as it stays continuously low when compared to the continent's external trade, as cited by Ebaidalla (2016).

The Common Market for Eastern and Southern Africa (COMESA) is one of Africa's regional economic communities, established to boost member states' economic growth and development by enhancing intra-trade 
and thereby deepening economic integration. COMESA's goal, according to Albert (2012), is to promote long-term economic and social development for all of its member countries through enhanced cooperation that leads to regional integration, particularly in the areas of trade, customs, infrastructure (transport and communications), science and technology, agriculture, and natural resources.

Despite these attempts, COMESA trade integration has had minimal success in terms of increasing trade volume among its member states. Some researchers, such as Alemayehu and Haile (2006), have suggested that the failure of trade integration is due to issues such as limited measures in fully reducing tariffs and eliminating non-tariff barriers, a lack of adoption of common economic policies, revenue loss, compensation issues, and poor private participation. Despite the development of RECs, the African continent has not been successful in growing intra-regional commerce, according to Geda and Seid (2015), and most of these regional economic communities have done very little.

As a result, the goal of this study is to investigate into the drivers of intra-COMESA trade that influence trade intensification across member states between 2000 and 2016. It should be remembered that intra-trade is one form of economic integration that plays a significant role in the region's economic development.

\subsection{Statement of the problem}

In Africa, regional integration has long been seen as a means of boosting economic growth by fostering intraregional commerce. It has also served as a tool for attaining industrialization and modernization by encouraging trade and securing economies of scale and market access (Khandelwal, 2004). A "spaghetti bowl" of interconnected and overlapping regional organizations has resulted from the enormous number of preferential trade agreements signed during the last five decades. Every African country is a member of at least one regional economic pact, with several belonging to five or more. Despite these attempts, intra-African trade continues to be limited. Regional exports account for less than ten percent of Africa's overall merchandise exports, and models that estimate trade potential between countries based on economic size, geographical distance, and other factors frequently find that trade between African economies falls short of expectations (World Bank, 2009).

Furthermore, some studies arrive at various conclusions as to why intra-trade has been restricted during the regional integration process. Issues of revenue loss, compensation issues, and variation in initial condition, poor private sector performance, lack of political commitment and institutional issues, issues of overlapping membership, high transaction costs due to inadequate infrastructure, macroeconomic instability, distorted 
trade regimes, low resource complementarity, and small market size characterize these poor intra-trade performances (Eden,2008).

Moreover, despite the continent's long history of regional integration, intra-African commerce remains low in compared to other developing regions. Intra-African exports are for $9.6 \%$ of total exports in the region, compared to $20 \%$ in Latin America and $48 \%$ in emerging Asia. This percentage is significantly larger in SubSaharan Africa (about 12\%) than in North Africa (approximately 3\%), which has historically had relatively low levels of intra-regional commerce (AfDB, 2011). Regional integration, according to the ECA, is a vital strategy for growth and intra-trade, and it is predicted to bring significant economic benefits to Africa. Despite widespread recognition that intra-African commerce has the potential to accelerate economic growth, reduce poverty, and improve food and energy security in Africa, the continent continues to trade little among itself.

Unlike other regional commercial blocs, COMESA's regional integration has not resulted in increased commerce among member nations. As a result, intra-trade growth in ASEAN and SADC was 1.20 percent and 8.80 percent, respectively, from 1980 to 1990, while it was just 0.60 percent in COMESA. Between 1990 and 1995, when the three areas chose to establish free trade agreements among its members, intra-regional trade grew at 1.90 percent for ASEAN, 2.90 percent for SADC, and barely 0.15 percent for COMESA (Umurungi, cited by Ibrahim \& Obiageli, 2015).

\subsection{Objectives of the study}

The study's goal is to determine the magnitude of export trade through trade-linkage and to identify each member's major trade partners, with a focus on the potential expansion of export trade flows among COMESA members.

\subsection{Significance of the study}

This study aims to improve understanding of the factors of intra-trade performance in the Economic Community of Africa in general, and COMESA member states in particular, by identifying areas where COMESA may improve and new actions that can be adopted to promote intra-trade. This research makes several valuable contributions to policymakers seeking a thorough understanding of intra-trade variables.

The study will allow COMESA member states to think about their policies and regulations in terms of trade intensity, multi-membership, good governance, and other cost-related concerns that affect intra-trade within the bloc. International development partners and investors can use this information to help them decide 
whether or not to engage in the development process by developing bilateral trade policies with COMESA member states.

Finally, I hope to contribute to the current literature, academicians, and researchers in the field of COMESA trade. The research will provide the most up-to-date information on trade flows.

\subsection{Scope the study}

This study is limited to COMESA member countries such as Burundi, DRC, Comoros, Djibouti, Egypt, Eritrea, Ethiopia, Kenya, Libya, Madagascar, Malawi, Mauritius, Rwanda, Seychelles, Sudan, Swaziland, Zambia, Uganda, and Zimbabwe, as well as six IGAD members such as Ethiopia, Djibouti, Eritrea, Kenya, Uganda, and South Sudan, based on the availability of balanced panel data until 2016.

\subsection{Organization of the study}

This research is divided into five sections. The study's first chapter contains an introduction to the research, as well as the problem statement, objectives, significance, scope, and limitations. The second chapter focuses on a literature review that is directly related to the issues and variables being studied, including conceptual framework and empirical, theoretical, and theoretical literature. The third chapter discusses the study's methodological methodologies, which include the use of the trade intensity index. The fourth chapter delves into the findings and discussions. Based on the findings and conversations, Chapter 5 draws certain conclusions and policy implications.

\section{LITERATURE REVIEW}

\subsection{Theoretical review on regional integration}

Regional economic integration may be defined as an attempt to link together the economies of two or more countries, in defined geographic areas, designed to reduce economic barriers such as tariffs and immigration controls, aimed at raising the living standards as well as achieving peaceful relations among the participating countries (Murinde, 2001).

Depending upon the level of integration amongst participating nation-states, RTAs can be divided into the following categories: Firstly, trade barriers are lowered when the countries conclude Preferential Trading 
Agreements (PTAs) at the most basic level. Such preferential trade is usually limited to the portion of actual trade flows from LDCs and is often non-reciprocal in nature. Papua New Guinea - Australia Trade represents an example of such an agreement.

Second, when two countries strike a bilateral trade agreement whereby trade barriers i.e. Tariffs are abolished among the participating countries; such an arrangement is called Free Trade Agreement/Area (FTA). However, each member is free to formulate its external trade policies against the countries, which are not part of FTA. Under this arrangement, barriers to trade are reduced gradually over a period, but it does not mean that all trade has become completely free of national barriers, which at times stay intact. A prominent example of an FTA is the North American Free Trade Agreement (NAFTA).

The formation of the Customs Union comes at the third level of economic integration. Customs Union is a stage where trade barriers among the member countries are abolished and a common external trade policy is adopted by the member nations (e.g. Common External Tariff regime or CET), vis-àvis non-members. A Customs Union can be likened to an FTA, which is accompanied by a common external trade policy. The Customs Union of the Southern Cone-Mercosur- can be referred to as an example in this regard.

The Common Market represents the fourth level in the process of economic integration. A Common Market is established when the member countries facilitate movement of both goods and factors by removing all trade barriers. They also continue to retain the common external trade policy. It can be likened to a Customs Union plus free mobility of factors of production. The relevant example of a common market is the Common Market for Eastern and Southern Africa (COMESA).

Economic Union is the climactic point and the last level of economic integration. The participating countries pursue common macroeconomic policies in an Economic Union and also allow free movement of goods and factors. An example of Economic Union is manifestly the European Union (Jovanović cited in Qadri, 2012).

Table 1: Types and characteristics of International Economic Integration 


\begin{tabular}{|c|c|c|c|c|c|}
\hline $\begin{array}{l}\text { Type } \\
\text { Acticy }\end{array}$ & $\begin{array}{l}\text { Free } \quad \text { Trade } \\
\text { Area }\end{array}$ & $\begin{array}{l}\text { Customs } \\
\text { Union }\end{array}$ & $\begin{array}{l}\text { Common } \\
\text { Market }\end{array}$ & $\begin{array}{l}\text { Economic } \\
\text { Union }\end{array}$ & $\begin{array}{l}\text { Total } \\
\text { Political } \\
\text { Union }\end{array}$ \\
\hline Removal of tariffs and quotas & $\nabla$ & $\nabla$ & $\nabla$ & $\nabla$ & $\nabla$ \\
\hline Common external tariff & & $\square$ & $\square$ & $\nabla$ & $\nabla$ \\
\hline Factor mobility & & & $\nabla$ & $\nabla$ & $\nabla$ \\
\hline $\begin{array}{l}\text { Harmonization of economic } \\
\text { policies }\end{array}$ & & & & $\nabla$ & $\nabla$ \\
\hline $\begin{array}{l}\text { Total unification of economic } \\
\text { policies }\end{array}$ & & & & & $\square$ \\
\hline
\end{tabular}

Source: David and Zainal (2013)

The formation of Regional Trade Agreements (RTAs) has two static effects; trade creation and trade diversion, the application of zero tariffs between COMESA member countries is expected to increase the intra-regional trade which means increasing imports and exports between member countries at the expense of that from non-member countries. This will create competitive environment that might affect the domestic production, consumption and welfare.

Urata and Okabe (2007) also strengthen this argument in that trade creation results in an improvement in resource allocation and economic welfare whereas trade diversion worsens efficiency in allocation of resource in the world as it replaces imports of highly efficient nonmember states by imports from less efficient member states. Trade creation takes place when a member country replaces its domestic production by imports from a more efficient partner state (at a relatively lower cost). On the other hand, trade diversion occurs when lower cost imports from outside the regional integration get replaced by higher cost imports from member states.

Umurungi (2005) has described some of the dynamic gains from Regional Integration Agreements (RIAs). The competition effect which brought about freeing imports from partner countries; the investment effect which appears when there are new foreign and domestic investments that have not occurred in the absence of RIA; and the structural transformation effect which is a shift from traditional primary-products exports to new industrial-products export. The dynamic effects of regional trade integration are potentially more significant than the static effects, because of their cumulative nature. 
Regional integration can foster competition, subsidiarity, access to wider market (via trade), larger and diversified investment and production, socio-economic and political stability and bargaining power for the countries involved. It can be multi-dimensional to cover the movement of goods and services (i.e. trade), capital and labour, socio-economic policy coordination and harmonization, infrastructure development, environmental management, and reforms in other public goods such as governance, peace, defense and security (Mothae cited in Yabu, 2014).

Regional trading agreements are pursued for a variety of reasons. A motivation of virtually every regional trade agreement has been the prospect of enhanced economic growth. An expanded regional market can allow economies of large-scale production, foster specialization and learning-by-doing, and attract foreign investment. Moreover, regionalism may enhance and solidify domestic economic reforms. East European nations, for example, have viewed their regional initiatives with European Union as a meaning of locking in their domestic policy shifts towards privatization and market-oriented reforms (Qadri, 2012).

Formation of economic blocs is motivated by the allocation effect and the growth effect arising from free trade within an economic bloc. The allocation effect requires that in a competitive economic system, resources are allocated to produce goods based on peoples' demand for those goods by interaction between consumers and producers. When tariffs and non-tariff barriers interfere with this signal, it becomes necessary to clear such barriers through regional integration. Regional integration could also lead to the creation of large markets which would allow access to small firms thus enabling them to reach optimal sizes lowering costs and prices for the consumers. It expands regional markets, attracts more suppliers to these markets and gives firms the opportunity to specialize, increase the mobility of human capital, technological spillovers, an increase in productivity and the reduction of production costs which help to attract more investment and capital accumulation. The location decision of foreign firms can be significantly influenced by the formation of trade blocs (Baldwin cited in UNCTAD, 2009).

\subsection{Empirical literature review}

Albert (2012) analyses the impact of regional trade agreements on intra-trade in selected agro-food products (i.e. maize, rice and wheat) in three regional economic communities (RECs) namely COMESA, EAC and SADC. The study finds that geographic distance impacts the intra-regional trade in these commodities negatively; whereas the GDP of the partner countries have the expected positive signs. Besides the traditional determinants of bilateral trade, the author finds positive and significant coefficients for the regional trading 
blocs which imply that these trading blocs promote intra-regional trade in the commodities. Usually geographic distance measures the cost of transport.

Martinez and Nowak (2001) explored the determinants of bilateral trade flows between the European Union and Mercosur applying the gravity model in panel data framework and analyzed the trade potential between the two trading blocs. The authors found that the partners' incomes had the expected positive impact on bilateral trade flows and the income elasticity of trade flows was found to be near unity in line with the theoretical expectation. But the effect of the exporting and importing countries' population is opposite; exporting countries' population has large negative coefficients, implying domestic absorption effect whereas that of importing countries' has large positive impact suggesting that highly populated countries import more compared to those less populated countries. Exchange rate and income differences were also found to be important determinants of trade flow in these two trading blocs.

Abidin, Abu Bakar and Sahlan (2013) investigated the impact of economic factors on bilateral exports between Malaysia and the Organization of Islamic Cooperation (OIC) member countries . Using the panel estimation for gravity model, the data covers the period of 1997 to 2009 . The gravity estimates imply the importance of size effects, level of openness of the economy, inflation rates, and the exchange rates as determinant of Malaysia's exports to OIC countries. The estimation of individual effects shows the significance of distance and institutions in enhancing Malaysia-OIC exports.

Henry (2015) examined the effect of regional economic integration on exports in the COMESA region using the fixed effects regression, random effects regression and instrumental variables GMM regression to estimate an augmented trade gravity model using panel data from 1980 to 2012. The study results showed that the formation of COMESA trading bloc has promoted intra-regional exports, implying intra-COMESA export bias. Comparing pre-COMESA (1980-1993) and post-COMESA (1994-2012) periods, it was found that intraCOMESA exports have grown by approximately 35 percent since COMESA was formed. The study suggests that to enhance export flows in the region, the process of economic integration should be deepened. Thus, there is need for increased investment in transport infrastructure that will reduce long distance cost of doing business. This would have a major impact on deepening integration of COMESA economies.

Keane, et al. (2010) studied on impediments to intra-regional trade in Sub-Saharan Africa. A quantitative methodology used for the assessment of the impact of NTBs on trade flows is developed and then applied to the Southern African Development Community (SADC). Based on their results of a quantitative assessment of the identified impacts of NTBs on intra-regional trade, they suggested that policy measures addressing 
should be undertaken to solve the impediment. Yabu (2014) assessed the intra-SADC trade in goods and services using relative intra-trade intensity and gravity model and conclude that one of the objectives of regional integration is to reduce trade barriers in order to promote and boost trade among member states. However, a small share of exports and imports within the SADC region depicts a slow improvement in trade among member states. Therefore, most of SADC member states appear to trade more with other countries outside the SADC region.

Geda and Kibret (2002), critically reviews major issues of regional economic integration in Africa which are related to the issues of the economic, political and institutional constraints that surface at the implementation stage of economic integration treaties using the experience of COMESA as a case study and tests the determinants of trade flows. Their major conclusions indicate that first, bilateral trade flows among the regional groupings could be explained by standard variables as demonstrated by the results of the conventional gravity model, while regional groupings have had insignificant effect on the flow of bilateral trade. And, second, the review of the issues indicates that the performance of regional blocs is mainly constrained by problems of variation in initial condition, compensation issues, real political commitment, overlapping membership, policy harmonization and poor private sector participation.

The limited growth in intra-regional trade in COMESA can be attributed to many causes. However, the lack of diversity and the similarity of the products exported by member countries, the lack of political commitment to integration, lack of security and political stability, poor physical infrastructure, macro-economic imbalances and unequal distribution of gains from integration are major constraints on increasing intraregional trade in COMESA (Sheriff \& Nwokedi,2015).

Trade intensity index measures the "pure" intensification of trading relationship. An increase in trade with a country may be attributable to two factors. One is the expansion of trade by a trading partner and the other is "pure" intensification of the trade relationship. Specifically, trade relationship of a country with (or trade dependency of a country on) a trading partner country can increase when the trading partner's trade expands faster than other countries. Trade intensity index captures the "bias" in bilateral trade relationship by considering the trade volume of the trading partner. Trade relationship is more (less) intensive (or biased) than normal if the value of trade intensity is greater (less) than unity (Urata \& Okabe, 2007). 


\section{METHODOLOGY}

\subsection{Research Design}

To achieve the study's goals, researchers used quantitative design methodologies to examine intra-regional trade among member countries of the Common Market for Eastern and Southern Africa from 2000 to 2016. The trade intensity index was employed in the study to assess the trade pattern and determine whether improved cooperation between COMESA countries is conceivable.

Annual total bilateral export trade statistics from the IMF, Direction of Trade Statistics (DOTS), UN COMTRADE data base, World Integrated Trade Solution, World Development Indicators (WDI) database, CEPII, AU, and UNECA are among the data sources.

\subsection{Study area}

The study area includes the nineteen (19) members of the Common Market for Eastern and Southern Africa (COMESA), one of Africa's eight recognized regional economic communities. COMESA's goal is to enhance commerce among its members in order to boost economic growth and development through regional economic integration.

\subsection{Data collection and sources}

This section presents variables and sources of data used in the study. The analysis covers a cross section of 19 COMESA member states and time series from 2000 to 2016. The researcher uses secondary data sources to collect information from the different international organizations data bases. This has been found appropriate because of the credibility and recognizable data availability for the research study for each member country in COMESA region. Document review technique was also used to collect secondary data necessary for the research study.

Annual total bilateral export trade data in thousands of US dollars was obtained from Direction of Trade Statistics (DOTS), UN Commodity Trade Statistics (UN COMTRADE) online data base, World Integrated Trade Solution. Annual GDP or populations of a country as a proxy for economic size are obtained from World Development Indicators (WDI) database. 


\subsection{Method of data analysis}

\subsubsection{Model specification}

In this sub-section, we proceed to specify the models that are used to measure and analyses the bilateral trade to addresses each specific research questions.

\subsubsection{Measures of intra-regional trade intensity index}

To answer the research question, the study uses the trade intensity index to calculate a relative intra-trade intensity measure between COMESA member states, which is used to assess the trade pattern and determine whether improved cooperation is possible between COMESA members. For the period 2000 to 2016, the Trade Intensity Index was produced using data from the Direction of Trade Statistics (DOTS) and the World Development Indicator (WDI). A number of one implies that bilateral trade follows the global trend; while a value greater than one suggests that trade intensity exists between partners.

According to Hyun and Hong (2005) the measure can be expressed as follows:

$T I_{i j}=\frac{\frac{x_{i j}}{\sum_{j} X_{i j}}}{\frac{\sum_{i} X_{i j}}{\sum_{i} \Sigma_{j} X_{i j}}}$

Where $\mathrm{X}$ ij is country i's exports going to country $\mathrm{j}$. The numerator indicates the share of country i's export to country $\mathrm{j}$ in total export of the country $\mathrm{i}$, and the denominator indicates the share of country j's imports of the total world imports. If the bilateral trade intensity index has a value greater than 1 , the export of country $\mathrm{i}$ outperforms in country $\mathrm{j}$ considering country i's export ability and country j's import capacity. It implies that country $\mathrm{j}$ is relatively important to country $\mathrm{i}$. If the bilateral trade intensity index has a value smaller than 1 , country $\mathrm{j}$ is not relatively important for country $\mathrm{i}$ 's export. 


\section{RESULTS AND DISCUSSIONS}

\subsection{Trends and patterns of intra-trade in COMESA}

This section analyses COMESA's intra-trade trends and patterns utilizing up-to-date trade data in order to better grasp the study's backdrop before moving on to the next data analysis. It examines the primary trading trends and member makeup.

The Direction of Trade Statistics (DOTS) disaggregated the value of merchandise exports and imports by the key trading partners of a country. Imports are valued at cost, insurance, and freight (CIF), while exports are valued at free on board (FOB). Kenya is the leading exporting country among the COMESA trading bloc's 19 members, including agricultural items, particularly tea and tobacco, and animal products, as well as emerging as the top performer in the EAC and acting as the largest trade market in east Africa.

Table 2 shows that intra-export values for all COMESA members fluctuated over time. The intra-export values in the region are dominated by Kenya and Egypt. Kenya exported goods worth \$1,459.2 million in 2008 and \$1,553.4 million in 2015. Egypt, after Kenya, has the second greatest proportion of exports among COMESA members, with \$1,084.0 million in 2008 and \$1,654.0 million in 2015. Between these years, both countries had increasing GDP and FDI inflows, which aided in the manufacturing of goods and services for export to other members. In 2008, the Democratic Republic of Congo was the third-largest seller of goods, with $\$ 578.2$ million in sales, which climbed to \$999.6 million in 2015 . 
Table 1: Intra-export within COMESA bloc in million USD values (2008-2015)

\begin{tabular}{lllllllll}
\hline Country & 2008 & 2009 & 2010 & 2011 & 2012 & 2013 & 2014 & 2015 \\
\hline Burundi & 8.3 & 11.2 & 12.0 & 22.0 & 31.0 & 40.8 & 54.0 & 52.4 \\
Comoros & 0.2 & 0.4 & 2.3 & 2.9 & 0.9 & 1.0 & 0.5 & 0.7 \\
Congo* & 578.2 & 529.5 & 1303.8 & 1391.9 & 1345.9 & 1864.7 & 1492.9 & 999.6 \\
Djibouti & 25.9 & 166.2 & 158.3 & 186.2 & 145.1 & 127.8 & 130.6 & 165.5 \\
Egypt & 1084.0 & 1324.2 & 1736.6 & 1134.6 & 2480.0 & 2408.0 & 1977.1 & 1654.0 \\
Eritrea & 0.5 & 1.6 & 0.2 & 4.5 & 4.6 & 2.8 & 4.2 & 3.0 \\
Ethiopia & 7.3 & 4.4 & 22.4 & 43.1 & 42.2 & 1091.9 & 1092.8 & 1088.7 \\
Kenya & 1459.2 & 1253.5 & 1421.1 & 2014.8 & 1822.8 & 1694.7 & 1665.0 & 1553.4 \\
Libya & 228.0 & 214.5 & 330.9 & 320.7 & 363.4 & 342.7 & 350.5 & 390.5 \\
Madagascar & 36.2 & 31.2 & 50.3 & 42.6 & 40.2 & 53.4 & 66.4 & 61.3 \\
Malawi & 85.4 & 171.5 & 219.9 & 310.4 & 163.2 & 144.5 & 246.9 & 211.9 \\
Mauritius & 171.7 & 152.2 & 156.1 & 188.8 & 213.9 & 198.4 & 218.2 & 225.7 \\
Rwanda & 211.8 & 130.5 & 82.2 & 124.9 & 305.4 & 311.6 & 330.0 & 159.4 \\
Seychelles & 3.2 & 1.3 & 2.3 & 247.3 & 4.2 & 2.9 & 2.2 & 2.6 \\
Sudan & 120.7 & 217.8 & 353.5 & 427.3 & 428.3 & 282.7 & 445.6 & 469.4 \\
Swaziland & 78.8 & 40.9 & 30.1 & 26.3 & 19.5 & 15.1 & 15.8 & 22.3 \\
Uganda & 721.9 & 713.1 & 791.0 & 997.0 & 1216.1 & 1096.2 & 879.3 & 961.4 \\
Zambia & 850.1 & 635.8 & 695.6 & 966.9 & 1500.6 & 1878.6 & 1277.8 & 975.1 \\
Zimbabwe & 173.0 & 145.9 & 178.7 & 147.3 & 121.0 & 135.4 & 113.9 & 101.9 \\
\hline Source: Author
\end{tabular}

Source: Author, compiled from IMF, DOTS accessed on December/2017.

Burundi, Comoros, Eritrea, Swaziland, and the Seychelles, on the other hand, were relatively minor players in the region, with the least intra-export commerce. In 2015, the three countries' total export value was nearly equal to Egypt's, potentially lowering COMESA's overall trading patterns in comparison to other parts of the world. COMESA's intra-regional exports increased from 5,844 million in 2008 to 11,693 million in 2013. This demonstrates some dynamism, which is good news for expanding intra-COMESA trade, which might be boosted by other members' improving export levels, albeit a more detailed analysis of the composition of such trade at the disaggregate level is required. Intra-regional export trade, on the other hand, fell to $\$ 9,099$ million in 2015(see figure 1). 
Figure 1: COMESA total intra-export in million USD from 2008 to 2015

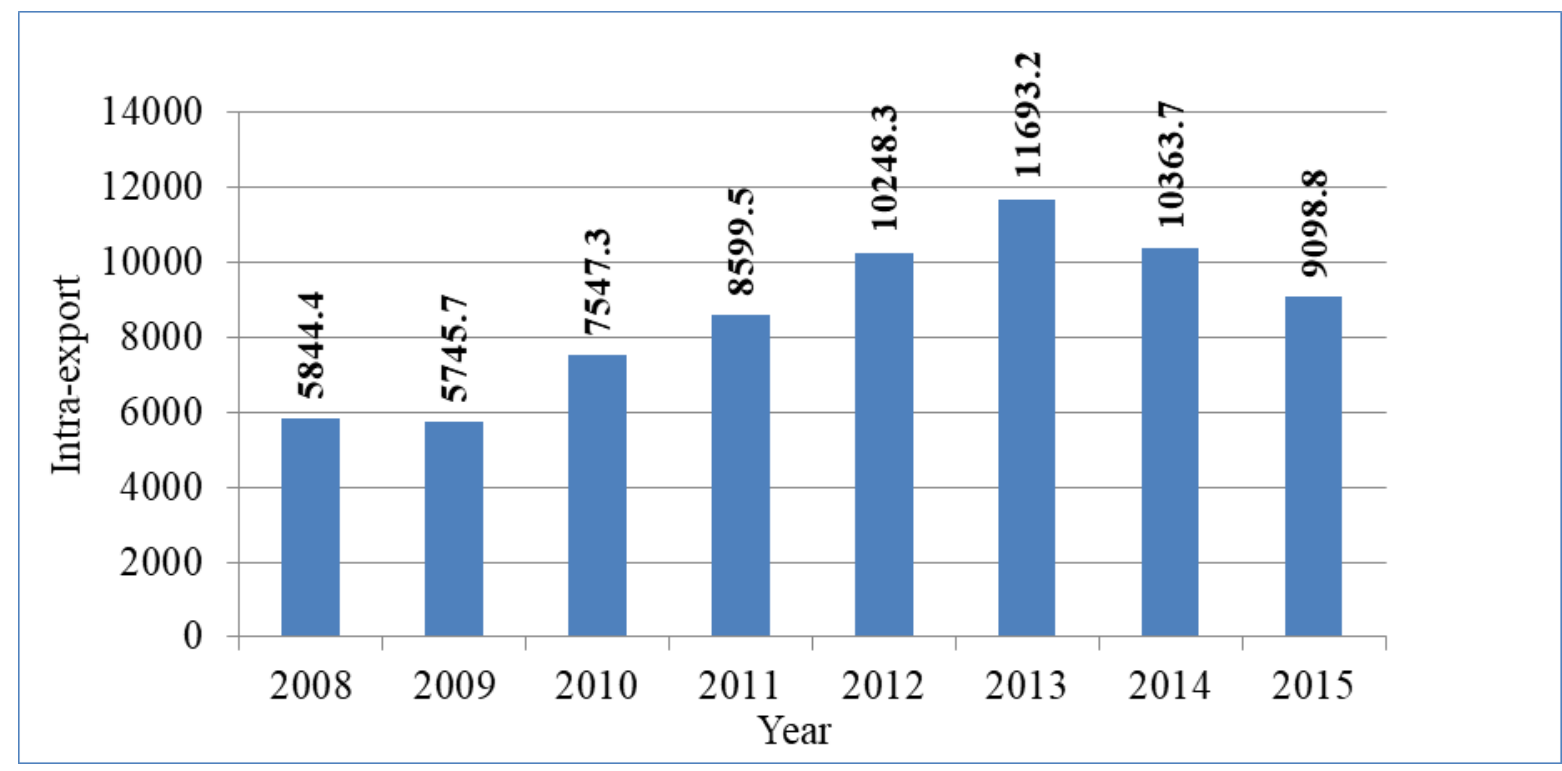

Source: Author, computed based on IMF, (DOTS), 2017 
Table 2: Intra-import within COMESA bloc in million USD values

\begin{tabular}{llllllllll}
\hline Country & $\mathbf{2 0 0 8}$ & $\mathbf{2 0 0 9}$ & $\mathbf{2 0 1 0}$ & $\mathbf{2 0 1 1}$ & $\mathbf{2 0 1 2}$ & $\mathbf{2 0 1 3}$ & $\mathbf{2 0 1 4}$ & $\mathbf{2 0 1 5}$ & $\mathbf{2 0 1 6}$ \\
\hline Burundi & 94.1 & 99.5 & 118.6 & 155.3 & 159.6 & 147.9 & 102.3 & 89.6 & 100.5 \\
Comoros & 6.3 & 7.1 & 11.4 & 7.0 & 6.8 & 18.9 & 18.6 & 15.7 & 15.7 \\
Congo DRC & 679.5 & 693.2 & 785.2 & 920.1 & 1420.9 & 2005.2 & 1531.0 & 1074.2 & 944.6 \\
Djibouti & 9.5 & 56.6 & 43.8 & 55.5 & 72.2 & 78.3 & 96.1 & 131.4 & 145.4 \\
Egypt & 1090.5 & 660.8 & 917.7 & 878.6 & 834.7 & 710.4 & 650.2 & 556.9 & 366.1 \\
Eritrea & 22.9 & 47.4 & 106.5 & 64.8 & 96.8 & 91.9 & 51.4 & 59.7 & 29.6 \\
Ethiopia & 154.7 & 160.5 & 168.8 & 146.4 & 231.2 & 179.0 & 292.3 & 338.3 & 288.6 \\
Kenya & 420.7 & 310.8 & 493.1 & 602.4 & 714.4 & 663.6 & 658.1 & 816.8 & 888.8 \\
Libya & 173.6 & 311.6 & 628.2 & 187.8 & 441.1 & 513.8 & 413.5 & 225.6 & 199.2 \\
Madagascar & 139.6 & 98.0 & 203.2 & 204.2 & 147.2 & 131.7 & 176.2 & 167.4 & 177.6 \\
Malawi & 185.4 & 176.0 & 236.0 & 227.2 & 190.2 & 237.3 & 230.9 & 232.4 & 249.3 \\
Mauritius & 137.1 & 101.0 & 132.1 & 153.0 & 153.9 & 170.1 & 159.1 & 171.3 & 208.3 \\
Rwanda & 387.1 & 305.4 & 389.6 & 414.7 & 468.1 & 434.3 & 504.5 & 447.1 & 426.7 \\
Seychelles & 50.0 & 51.2 & 46.7 & 55.5 & 46.4 & 45.4 & 56.0 & 84.9 & 49.2 \\
Sudan & 597.2 & 582.0 & 797.9 & 648.9 & 724.9 & 861.1 & 617.9 & 719.6 & 715.3 \\
Swaziland & 6.1 & 5.7 & 91.3 & 87.7 & 81.1 & 82.5 & 106.0 & 75.6 & 70.8 \\
Uganda & 596.8 & 579.5 & 609.5 & 746.4 & 709.4 & 653.9 & 723.0 & 679.7 & 559.2 \\
Zambia & 836.7 & 688.8 & 1457.0 & 1642.6 & 1872.8 & 2794.4 & 2529.6 & 2009.8 & 1512.7 \\
Zimbabwe & 1164.7 & 1114.8 & 1213.2 & 1264.4 & 1255.1 & 1323.2 & 1231.4 & 1294.1 & 1236.5 \\
\hline
\end{tabular}

Source: Author, compiled from IMF, DOTS accessed on December, 2017.

Zambia, Zimbabwe, and the Democratic Republic of Congo were the top three intra-import countries inside the COMESA bloc, as seen in Table 3. As a result, the value of Zambia's intra-imports grew from $\$ 836.7$ million in 2008 to $\$ 1,513$ million in 2016. In the same way, Zimbabwe was the second best performer in intra-import, increasing from \$1164.7 million to \$1,237 million between 2008 and 2016. The Democratic Republic of Congo, which has been plagued by internal political unrest, came in third, importing commodities worth \$ 679.5 million in 2008 and \$945 million in 2016. Despite the fact that nations like Comoros, Eritrea, Swaziland, and the Seychelles are not landlocked; their contribution in intra-regional commerce has been inadequate, with Zimbabwe's intra-import exceeding two times their total intra-import for each year.

Figure 2 depicts intra-COMESA trade levels from 2000 to 2016. Between 2000 and 2013, intra-COMESA trade grew somewhat, as did extra-COMESA trade. However, COMESA's intra-trade performance began to deteriorate rapidly after 2013. COMESA's intra-export was $\$ 1,499$ million in 2000 , but it climbed to $\$ 11,693$ million in 2013, representing an annual growth rate of 11\%. However, between 2013 and 2016, the intraexport trend region fell from 11,693 to 7,854 million. COMESA's intra-imports among its members have followed a similar pattern. COMESA's intra-import climbed from \$1,293 million in 2000 to $\$ 11,143$ million in 2013 , indicating annual exponential growth of $10 \%$, which was $1 \%$ lower than intra-export over the same 
period. However, following 2013, COMESA's intra-imports fell from 11,143 to 8,184 million in 2013 and 2016, respectively.

Figure 2: Trends of intra-export and import of COMESA

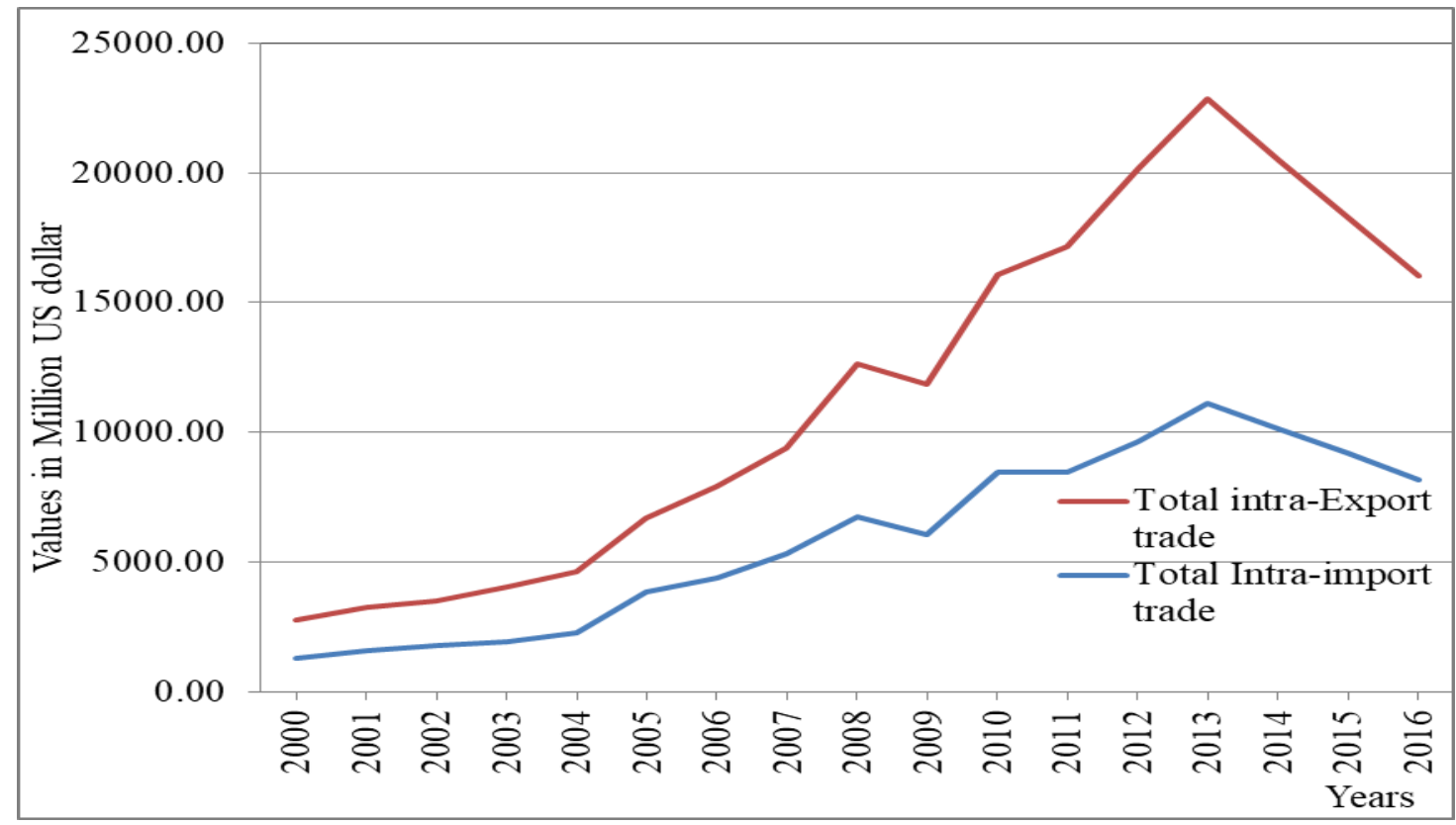

Source: Author, calculated from IMF, DOTS accessed on December, 2017

Table 4: Top ten COMESA intra-export, import and export commodities from/to the world measured in \%age (2013-2016)

\begin{tabular}{|l|l|l|l|l|l|l|l|l|l|l|l|l|}
\hline & \multicolumn{2}{l}{$\begin{array}{l}\text { Intra-Export Trade within COMESA } \\
\text { members }\end{array}$} & \multicolumn{2}{l}{$\begin{array}{l}\text { Imports of COMESA members from } \\
\text { the world }\end{array}$} & \multicolumn{2}{l|}{$\begin{array}{l}\text { Exports of COMESA members to the } \\
\text { world }\end{array}$} \\
\hline Products & $\mathbf{2 0 1 3}$ & $\mathbf{2 0 1 4}$ & $\mathbf{2 0 1 5}$ & $\mathbf{2 0 1 6}$ & $\mathbf{2 0 1 3}$ & $\mathbf{2 0 1 4}$ & $\mathbf{2 0 1 5}$ & $\mathbf{2 0 1 6}$ & $\mathbf{2 0 1 3}$ & $\mathbf{2 0 1 4}$ & $\mathbf{2 0 1 5}$ & $\mathbf{2 0 1 6}$ \\
\hline $\begin{array}{l}\text { Mineral fuels, } \\
\text { oils and their } \\
\text { products }\end{array}$ & 4.09 & 4.51 & 9.90 & 4.26 & 14.80 & 15.51 & 13.88 & 12.62 & 45.16 & 31.08 & 21.70 & 15.73 \\
\hline $\begin{array}{l}\text { Ores, slag and } \\
\text { ash }\end{array}$ & 17.16 & 17.41 & 8.42 & 11.16 & 1.48 & 1.25 & 0.55 & 0.71 & 2.70 & 3.83 & 3.12 & 3.03 \\
\hline $\begin{array}{l}\text { Coffee, tea, \& } \\
\text { spices }\end{array}$ & 4.58 & 4.85 & 6.31 & 7.52 & 0.39 & 0.42 & 0.54 & 0.60 & 2.73 & 3.66 & 5.11 & 5.53 \\
\hline $\begin{array}{l}\text { Organic/ } \\
\text { inorganic } \\
\text { compounds of } \\
\text { precious } \\
\text { metals }\end{array}$ & 6.17 & 4.18 & 5.54 & 5.63 & 0.95 & 0.69 & 0.74 & 0.74 & 1.26 & 1.08 & 1.17 & 0.99 \\
\hline
\end{tabular}




\begin{tabular}{|l|l|l|l|l|l|l|l|l|l|l|l|l|}
\hline $\begin{array}{l}\text { Salt, Sulphur, } \\
\text { earths \& stone, } \\
\text { \& cement }\end{array}$ & 6.09 & 5.07 & 4.01 & 4.48 & 1.08 & 1.13 & 0.84 & 0.79 & 1.12 & 0.99 & 1.16 & 1.13 \\
\hline $\begin{array}{l}\text { Sugars \& } \\
\text { sugar } \\
\text { confectionery }\end{array}$ & 3.27 & 3.29 & 3.78 & 6.49 & 1.09 & 0.95 & 0.90 & 1.35 & 1.49 & 1.72 & 1.89 & 2.14 \\
\hline $\begin{array}{l}\text { Tobacco \& } \\
\text { manufactured } \\
\text { tobacco } \\
\text { substitutes }\end{array}$ & 2.93 & 3.31 & 3.44 & 2.79 & 0.70 & 0.64 & 0.53 & 0.45 & 1.87 & 2.26 & 2.60 & 2.85 \\
\hline $\begin{array}{l}\text { Plastics \& } \\
\text { articles thereof }\end{array}$ & 3.73 & 3.84 & 3.35 & 2.88 & 3.94 & 3.99 & 4.07 & 4.23 & 1.60 & 2.17 & 2.32 & 2.05 \\
\hline Iron \& steel & 3.00 & 3.35 & 2.72 & 2.90 & 4.19 & 4.30 & 4.05 & 3.87 & 1.40 & 1.54 & 1.13 & 1.32 \\
\hline $\begin{array}{l}\text { Machinery, } \\
\text { mechanical } \\
\text { appliances, } \\
\text { nuclear } \\
\text { reactors }\end{array}$ & 2.73 & 3.13 & 2.06 & 1.86 & 10.64 & 9.77 & 9.18 & 9.87 & 0.60 & 0.97 & 0.74 & 0.71 \\
\hline
\end{tabular}

Source: Author, compiled from International Trade Center, accessed on March, 2018.

Table 4 depicts COMESA's intra-trade among its members, as well as global commodity import and export trade from and to the world, from 2013 to 2016. Except for mineral fuels, mineral oils, coffee, tea, and spices, sugars, and sugar confectionery, COMESA's intra-trade performance was lower in comparison to global trade for all products. Sugars and sugar confectionery have climbed by 3.22 percent in intra-COMESA export trade from 2013 to 2016, which is more than other items. Coffee, tea, and spices grew at a rate of 2.94 percent. However, ore, slag, and ash are the most commonly trafficked products amongst COMESA members, followed by coffee, tea, and spices. Ores slag and ash made up about 11.16 percent of all COMESA commodities traded in 2016.

Mineral fuels, mineral oils, and their products, which accounted for 12.62 and 15.73 percent of COMESA's global import and export in 2016, were followed by Machinery, mechanical appliances, nuclear reactors, boilers for import and Coffee, tea, and spices for export, which accounted for 9.87 and 5.53 percent in 2016. Intra-African trade, like Africa's trade with the rest of the world, has been dominated by a small number of primary commodities. The principal commodities that African countries sell to one another are concentrated, and the minimal trade in manufactured goods may mostly be attributed to South Africa, Egypt, and other North African countries. Primary commodities (petroleum oils, vegetable oils, vegetable oils and fats, copper ores) and some (b) manufactures are the principal intra-group imports within RECs (tobacco, edible products, lime, cement).

Agricultural items, particularly coffee, tea, spices, sugar, sugar confectionaries, and ores, ash, and slag, dominated intra-COMESA trade in 2016 (Figure 3), accounting for roughly $26 \%$ of intra-export trade. Ethiopia, Uganda, and Kenya were the top coffee exporters in the region, while Kenya, Malawi, and Uganda were the top tea exporters. DR Congo and Zambia were the primary exporters of ore and minerals; Sudan, 
Egypt, Zimbabwe, and Ethiopia were the main exporters of gold. This analysis revealed that, while intraCOMESA trade has increased since the FTA was established, it remains relatively low in comparison to other regional trade blocs, which are still dominated by primary agricultural exports. To be competent and extend the market through its members as well as to the rest of the world, member countries must work hard to diversify their investments by investing in new products that have a competitive advantage.

Figure 3: Intra-COMESA top exports by product category 2016

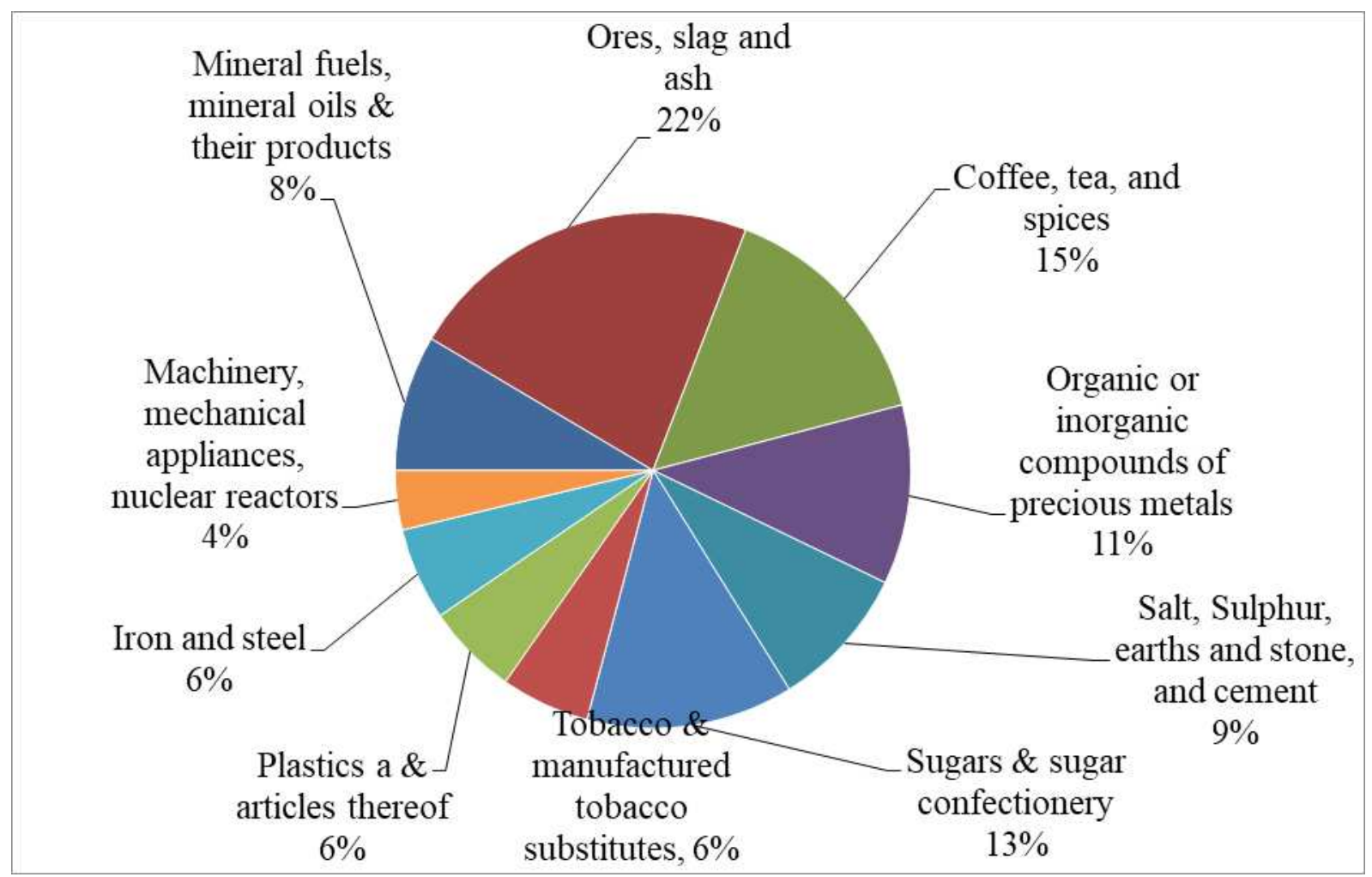

Source: Author, compiled from International Trade Center, accessed on March, 2018

Figure 4 shows a summary of COMESA intra-regional trade between 2000 and 2016. Throughout this time, intra-regional trade as a percentage of total commerce remained below 12 and rose by an average of $6 \%$. In comparison to its global market, intra-COMESA trade was inadequate. Intra-trade remains a modest part of global markets, and its volume has fluctuated over time. COMESA's intra-trade portion of its overall world merchandise exports increased by only $1 \%$ from 2000 to 2001 . These totals are low because some COMESA countries, such as Comoros, Eritrea, Swaziland, and Seychelles, have modest intra-trade patterns compared to their global commerce. 
During the years 2002 and 2003, however, the intra-trade share remained stable. The intra-trade share fell by 59 percent between 2004 and 2007, while the members' worldwide market performance improved. This demonstrates that the majority of COMESA member countries traded with the rest of the world in addition to their regional trade. However, from 2008 to 2015, intra-COMESA merchandise trade increased by 6\% of the region's total world commerce, and by 2015, the region's intra-trade share had dropped by $80 \%$. Despite the progress in trade, intra-COMESA exports accounted for less than a fourth of global merchandise exports from 2000 to 2016 . More than $80 \%$ of regional export trade was traded with other parts of the globe.

Figure 2: Share of intra-regional trade in total trade of COMESA (2000-2016)

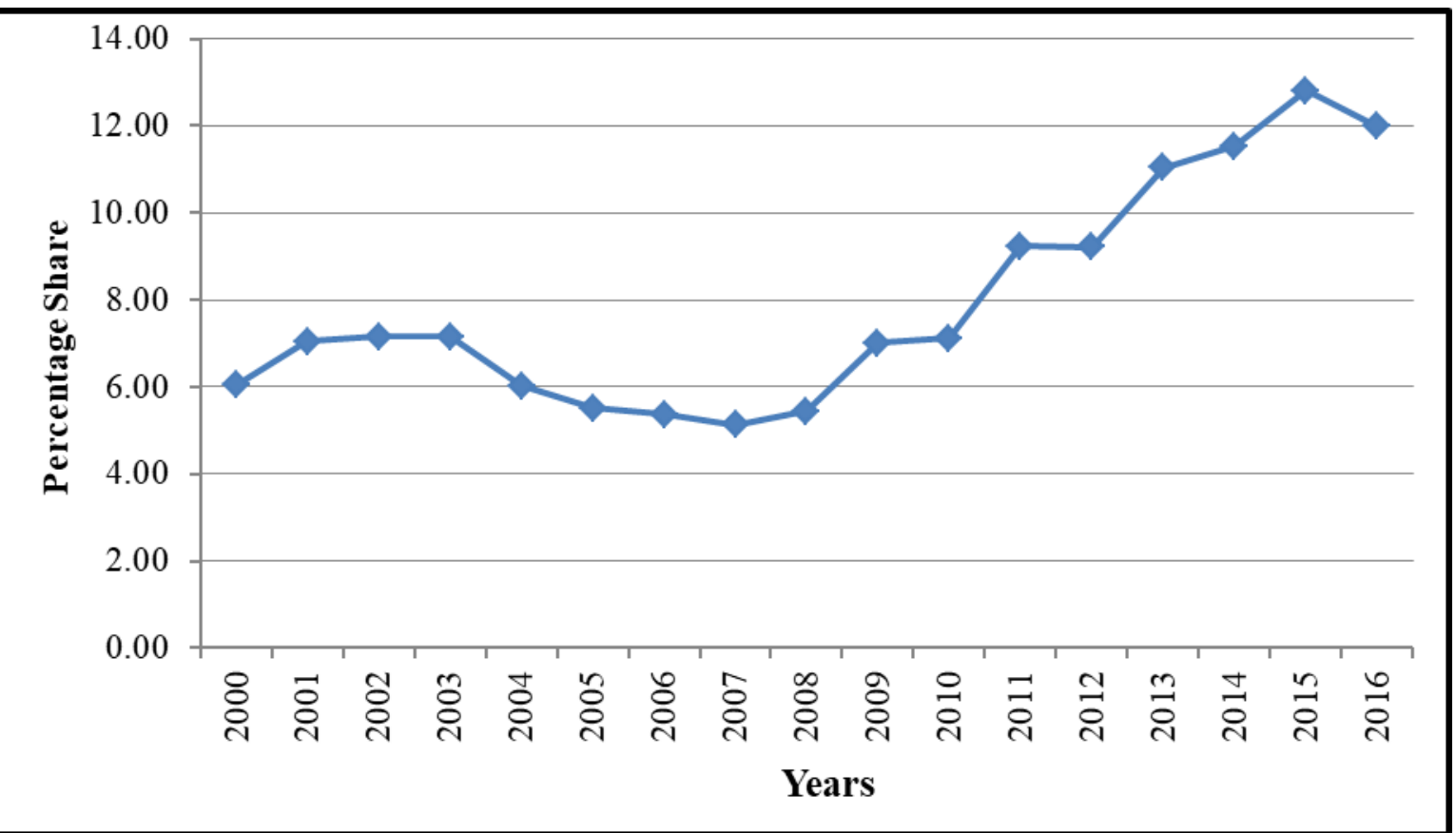

Source: Author, calculated with data from IMF, DOTS, accessed on December, 2017.

Increased intra-regional commerce has been one of Africa's Regional Economic Communities (REC) major areas for promoting regional integration. COMESA's intra-regional export performance was quite low in comparison to worldwide commerce, as shown in Table 5. COMESA exports account for over $85 \%$ of all exports outside of the area. COMESA's intra-trade performance has been inconsistent, declining from 2004 to 2008 before gradually improving from 2012 to 2016. In 2004, intra-COMESA exports totaled USD 2,352.1 
billion, accounting for 6.1 percent of the region's total exports. Between 2004 and 2016, COMESA's intraexport proportion of world trade climbed by 6.9\%, from 6.1 percent in 2004 to 13 percent in 2016.

Even while intra-regional commerce has expanded at a modest rate, intra-regional exports remain tiny in comparison to world exports, indicating a lack of integration among the members. Kenya dominated intraexport commerce among COMESA countries, accounting for three-quarters of overall regional trade. The majority of members export agricultural products both within their region and to the global market, and they do it at a reasonable cost in comparison to the rest of the world. The United States, Europe, China, and the United Arab Emirate were their main exporting partners.

Table 5: COMESA intra-regional and global export in million USD (2004-2016)

\begin{tabular}{cllc}
\hline Year & Intra-Export & Total Global & Share of Intra- \\
\hline 2004 & $2,352.1$ & $38,744.9$ & 6.1 \\
2005 & $2,845.2$ & $50,272.0$ & 5.7 \\
2006 & $3,543.3$ & $62,640.8$ & 5.7 \\
2007 & $4,032.4$ & $75,953.5$ & 5.3 \\
2008 & $5,904.5$ & $105,434.4$ & 5.6 \\
2009 & $5,815.4$ & $80,384.2$ & 7.2 \\
2010 & $7,647.1$ & $105,724.4$ & 7.2 \\
2011 & $8,699.4$ & $91,086.8$ & 9.6 \\
2012 & $10,548.4$ & $112,183.9$ & 9.4 \\
2013 & $11,693.1$ & $103,115.7$ & 11.3 \\
2014 & $10,363.7$ & $86,618.9$ & 12.0 \\
2015 & $9,098.4$ & $69,076.6$ & 13.2 \\
2016 & $7,854.0$ & $62,945.3$ & 12.5 \\
\hline
\end{tabular}

Source: Author, compiled from IMF, (DOTS) accessed on December, 2017.

Intra-regional import is the inverse of intra-regional export, since these measures assess the value of intraregional commerce from importing member nations. The value of intra-regional imports versus the total value of all imported items is a helpful indication of integration. Intra-import was also expressed as a percentage, as was intra-export, and could be calculated annually for each member country and for global import. This is a measure of the proportional importance of intra-regional imports in each member country's total import market (David \& Zainal, 2003).

COMESA's intra-import performance grew between 2000 and 2016, whereas the global intra-import share increased by 2.0 percent, a very little rise (Table 6). This low intra-import implies that the majority of 
COMESA member countries imported manufactured goods from non-member countries, namely the United States, Europe, China, and the United Arab Emirates. It demonstrates that COMESA's rate of integration through trade has slowed. Total exports to the rest of the world increased by 6.0 percent to US\$ 62,945.3 million in 2016, up from US\$ 38,744.9 million in 2004.

Table 6: COMESA intra-regional and global import in million USD (2000-2016)

\begin{tabular}{cccc}
\hline Year & Intra-Import & $\begin{array}{c}\text { Total } \\
\text { Global Import }\end{array}$ & $\begin{array}{c}\text { Share of } \\
\text { Intra-Import }\end{array}$ \\
\hline 2000 & 1293.1 & 31591.4 & 4.1 \\
2001 & 1605.8 & 31435.1 & 5.1 \\
2002 & 1781.9 & 32046.9 & 5.6 \\
2003 & 1960.0 & 33092.1 & 5.9 \\
2004 & 2297.2 & 43243.7 & 5.3 \\
2005 & 3855.9 & 55291.2 & 7.0 \\
2006 & 4403.1 & 62342.8 & 7.1 \\
2007 & 5351.6 & 75886.9 & 7.1 \\
2008 & 6752.6 & 117780.9 & 5.7 \\
2009 & 6049.8 & 109745.6 & 5.5 \\
2010 & 8449.8 & 133824.7 & 6.3 \\
2011 & 8462.4 & 141552.9 & 6.0 \\
2012 & 9627.1 & 162294.5 & 5.9 \\
2013 & 11142.9 & 166150.7 & 6.7 \\
2014 & 10148.3 & 169361.6 & 6.0 \\
2015 & 9190.1 & 163003.3 & 5.6 \\
2016 & 8184.0 & 135262.7 & 6.1 \\
\hline
\end{tabular}

Source: Author, compiled from IMF, accessed on December, 2017

For any Regional Trade Agreement (RTA) to be successful, it is imperative on partner countries to have complementary trade structure to be exploited for mutual benefit. Countries which got complementary trade structure are likely to trade more whereas economies with similar trade structure often struggle to improve trade share unless there is substantial intra industry trade (Chandran, 2010). But most of the African countries produce similar primary commodities which have been facing with problem of competition and low price in the global market.

In between 2000 and 2016, COMESA's intra-export share increased by only 5.3 percentage points from 4.9 percent in 2000 to 10.2 percent in 2016 and trade with rest of the world decreased by 5.3 percent from 95.1 in 2000 to 89.8 percent in 2016. According to UNCTAD (2012) the contribution of the regional economic communities in Africa towards intra-regional trade expansion has been negligible as the share of intraregional trade remains static. African countries remain on the margins of global trade flows. In 2008 and 2009, Africa accounted for an insignificant 3 percent of global exports and imports as compared to about 6 
percent for developing America and a massive 27-30 percent for developing. Even the 10 ASEAN countries together accounted for around 6 per cent of global trade, twice as high as Africa's share.

MO Ibrahim Foundation (2014) found out that, compared to other regions in the world, intra-African trade is lagging. Between 2007 and 2011, the average share of intra-African exports in total merchandize exports was 11 percent compared with intra-regional trade of 50 percent in developing Asia,21 percent in Latin America and the Caribbean and 70 percent in Europe. One of the reasons that make lower intra-trade among Africa is that most of the commodity-rich countries have historically traded primarily outside of Africa due to a legacy of colonial history, and other factors. Table 7 also verifies this concept in which most of the COMESA members trade goods and services more with outside their member states than their regional groups. 
Table 3: COMESA intra and extra-export merchandize trade measured in percentage

\begin{tabular}{|c|c|c|}
\hline Year & Intra \&Extra Trade & Percentage \\
\hline \multirow{2}{*}{2000} & Intra-Trade & 4.9 \\
\hline & TROW & 95.1 \\
\hline \multirow{2}{*}{2001} & Intra-Trade & 5.7 \\
\hline & TROW & 94.3 \\
\hline \multirow{2}{*}{2002} & Intra-Trade & 6.4 \\
\hline & TROW & 93.6 \\
\hline \multirow{2}{*}{2003} & Intra-Trade & 5.7 \\
\hline & TROW & 94.3 \\
\hline \multirow{2}{*}{2004} & Intra-Trade & 4.9 \\
\hline & TROW & 95.1 \\
\hline \multirow{2}{*}{2005} & Intra-Trade & 5.3 \\
\hline & TROW & 94.7 \\
\hline \multirow{2}{*}{2006} & Intra-Trade & 5.3 \\
\hline & TROW & 94.7 \\
\hline \multirow{2}{*}{2007} & Intra-Trade & 5.0 \\
\hline & TROW & 95.0 \\
\hline \multirow{2}{*}{2008} & Intra-Trade & 5.4 \\
\hline & TROW & 94.6 \\
\hline \multirow{2}{*}{2009} & Intra-Trade & 7.0 \\
\hline & TROW & 93.0 \\
\hline \multirow{2}{*}{2010} & Intra-Trade & 7.2 \\
\hline & TROW & 92.8 \\
\hline \multirow{2}{*}{2011} & Intra-Trade & 8.9 \\
\hline & TROW & 91.1 \\
\hline \multirow{2}{*}{2012} & Intra-Trade & 7.4 \\
\hline & TROW & 92.6 \\
\hline \multirow{2}{*}{2013} & Intra-Trade & 8.8 \\
\hline & TROW & 91.2 \\
\hline \multirow{2}{*}{2014} & Intra-Trade & 9.5 \\
\hline & TROW & 90.5 \\
\hline \multirow{2}{*}{2015} & Intra-Trade & 11.4 \\
\hline & TROW & 88.6 \\
\hline \multirow{2}{*}{2016} & Intra-Trade & 10.2 \\
\hline & TROW & 89.8 \\
\hline
\end{tabular}

Source: Author, compiled from UNCTAD accessed on February, 2017 
Figure 5 shows the causal relationship between FDI inflows to COMESA and intra-exports in million USD from 2000 to 2016. Looking at the figure the growth relationship between intra-trade and FDI inflows were positive and significantly increasing from 2000 to 2007. However, from 2007 to 2011 FDI inflows sharply decreasing while intra-export increases with slow rate. In the same way the two variables were also negatively associated from 2014 to 2016. This implies that during these periods the inward flows of FDI to COMESA had been decreased which negatively affects the intra-export volume of the region among its members. In other words intra-export trade of the COMESA was encouraged by local business production and government owned enterprises.

Figure 5: Relationship between intra-export and FDI inflows within COMESA

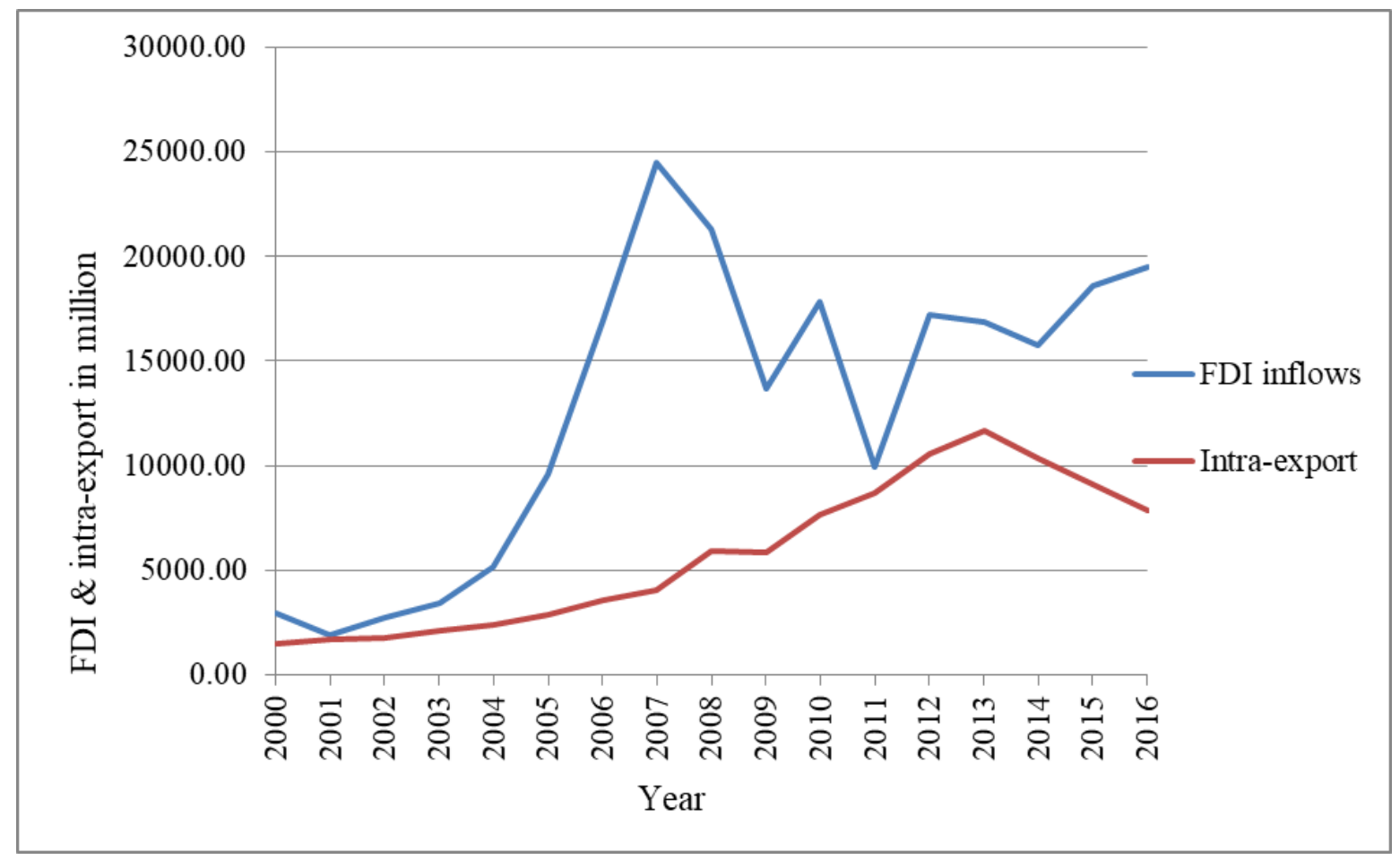

Source: Author, computation based on WDI data

\subsection{Presentation and discussion of the estimation results}

\subsubsection{Trade Intensity results and discussions}

In this section an attempt is made to construct the trade intensity index for the members of COMESA and to see whether the trade cooperation between these two trading partners are strong or weak. Furthermore, an 
analysis of trade intensity indices is used to estimate the extent of bilateral intra-trade linkages between members of COMESA individually and for the region as whole during the period 2000-2016 to answer objective one of the study. The trade intensity analysis technique appears suitable for this purpose. This technique is characterized by simplicity as well as the ability to identify the bilateral/multilateral trade linkages in clear terms (Qadri, 2012).

As a result, the Trade Intensity Index was calculated and displayed for each COMESA member by identifying the exporter and partners. The trade intensity index assesses how much a partner country's trading relationship is intensifying. There are two reasons for a rise in commerce with a country. One is a trading partner's extension of commerce, while the other is a "pure" intensification of the commercial connection. In particular, a country's trade connection with (or trade dependency on) a trading partner country can grow when the trading partner's trade increases faster than that of other countries (Urata \& Okabe, 2007).

We compute the trade intensity index and its changes over time with this element in mind. By taking the trading partner's trade volume into account, the trade intensity index quantifies the bias in bilateral trade relationships. Trade relationship is more (less) intensive (or biased) than normal if the value of trade intensity is greater (less) than unity.

Most neighboring COMESA countries appear to have a high trade intensity index, according to the computed results for each member. This demonstrates that the majority of countries want to trade more with bordering partner countries in order to reduce the cost of transportation of products and services connected with the region's members' distance. This is consistent with Wonnacott and Lutz's (1989) natural trading partner location and transit cost hypothesis, which states that geographical proximity between countries, tends to boost trade and prevent trade diversion. In addition, Deardorff and Stern (1994), also referring to transport costs, suggest that geographical proximity between countries tends to trade more with each other than with more distant countries to reduce transport and communication costs.

Table 8 presents the top four trade partners of exporting COMESA countries with a value more than unity in which an exporter country can intensify or increase trade quicker than other member states with a trade intensity less than unity, based on the Trade Intensity Index result. 
Table 8: Top four intra-trade partners of COMESA members

\begin{tabular}{ll}
\hline Exporter & $\begin{array}{c}\text { Partner who have trade intensity index greater than unity } \\
\text { with exporter }\end{array}$ \\
\hline Burundi & DRC Congo, Kenya, Rwanda, Uganda \\
Comoros & Djibouti, Madagascar, Mauritius, Seychelles \\
Congo(DRC) & Burundi, Rwanda, Zambia, Zimbabwe \\
Djibouti & Burundi, Egypt, Eritrea, Ethiopia \\
Egypt & Burundi, Eritrea, Libya, Sudan \\
Eritrea & Djibouti, Kenya, Sudan, Zimbabwe \\
Ethiopia & Djibouti, Sudan, Kenya, Comoros \\
Kenya & Burundi, DRC Congo, Malawi, Sudan \\
Libya & Egypt \\
Madagascar & Burundi, Comoros, Djibouti, Kenya \\
Malawi & Burundi, Kenya, Zambia, Zimbabwe \\
Mauritius & Comoros, Madagascar, Rwanda, Seychelles \\
Rwanda & Burundi, DR Congo, Swaziland, Uganda \\
Seychelles & Burundi, Madagascar, Mauritius, Sudan \\
Sudan & Egypt, Eretria, Ethiopia, Kenya \\
Swaziland & Madagascar, Sudan, Uganda, Zimbabwe \\
Uganda & Burundi, DR Congo, Kenya, Sudan \\
Zambia & DR Congo, Malawi, Mauritius, Rwanda \\
Zimbabwe & DR Congo, Malawi, Swaziland, Zambia \\
\hline
\end{tabular}

Source: Author, summary of trade intensity results

Accordingly, Burundi trades more with the Democratic Republic of Congo, Rwanda, Uganda, and Kenya, with trade intensity indexes of 30.9, 55.8, 92, and 76, respectively, from highest to lowest. However, commercial relations with Burundi were weak or below expectations for the remaining member countries. As a result, Burundi's trade intensity index with Comoros, Djibouti, Eritrea, and Ethiopia is high. Libya, Madagascar, Malawi, Seychelles, Swaziland, and Zimbabwe were all less than united, indicating a strained commercial relationship. This suggests that there may be other factors such as transport and logistical impediments that give rise to high transaction costs, or the lack of trade complementarities which account for the apparent low levels of trade (Pitigala, 2005).

For Djibouti, Kenya, Madagascar, Mauritius, Rwanda, and Seychelles, the trade intensity index was higher than unity. Other countries with a zero trade intensity index, such as Burundi, Eritrea, Libya, Swaziland, and Zimbabwe, did not trade with Comoros from 2000 to 2016. Zambia, Zimbabwe, Rwanda, Burundi, Uganda, and Kenya were the top to bottom trading partners for the Democratic Republic of Congo. However, the results suggest that Comoros, Djibouti, Ethiopia, Libya, and the Seychelles have no trade intensity. 
The bilateral trade relationship between Djibouti and Eretria was stronger than that of other members, indicating that the two nations were actively developing commerce. As a result, this study discovered that the intensity between two countries was high, with Ethiopia coming in second. Djibouti, on the other hand, was not traded with the Democratic Republic of Congo, Madagascar, or Zimbabwe, according to the data. This suggests that between 2000 and 2016, Djibouti did not expand its market potential in these nations.

The Trade Intensity Index between Egypt and other COMESA members is shown in Figure 6. Egypt is extending its trading options with all COMESA countries, with the exception of Madagascar and Malawi, where the TII for the majority of them is greater than one. Libya and Eretria were Egypt's most popular trade destinations, with TIIs of 48 and 37, respectively. This suggests that Egypt traded far more with Libya and Eritrea than one might expect from other COMESA members. Madagascar and Malawi had the lowest trade potential of Egypt, with TIIs of 0.46 and 0.68 , respectively.

Figure 6: Trade intensity index between Egypt and other members of COMESA

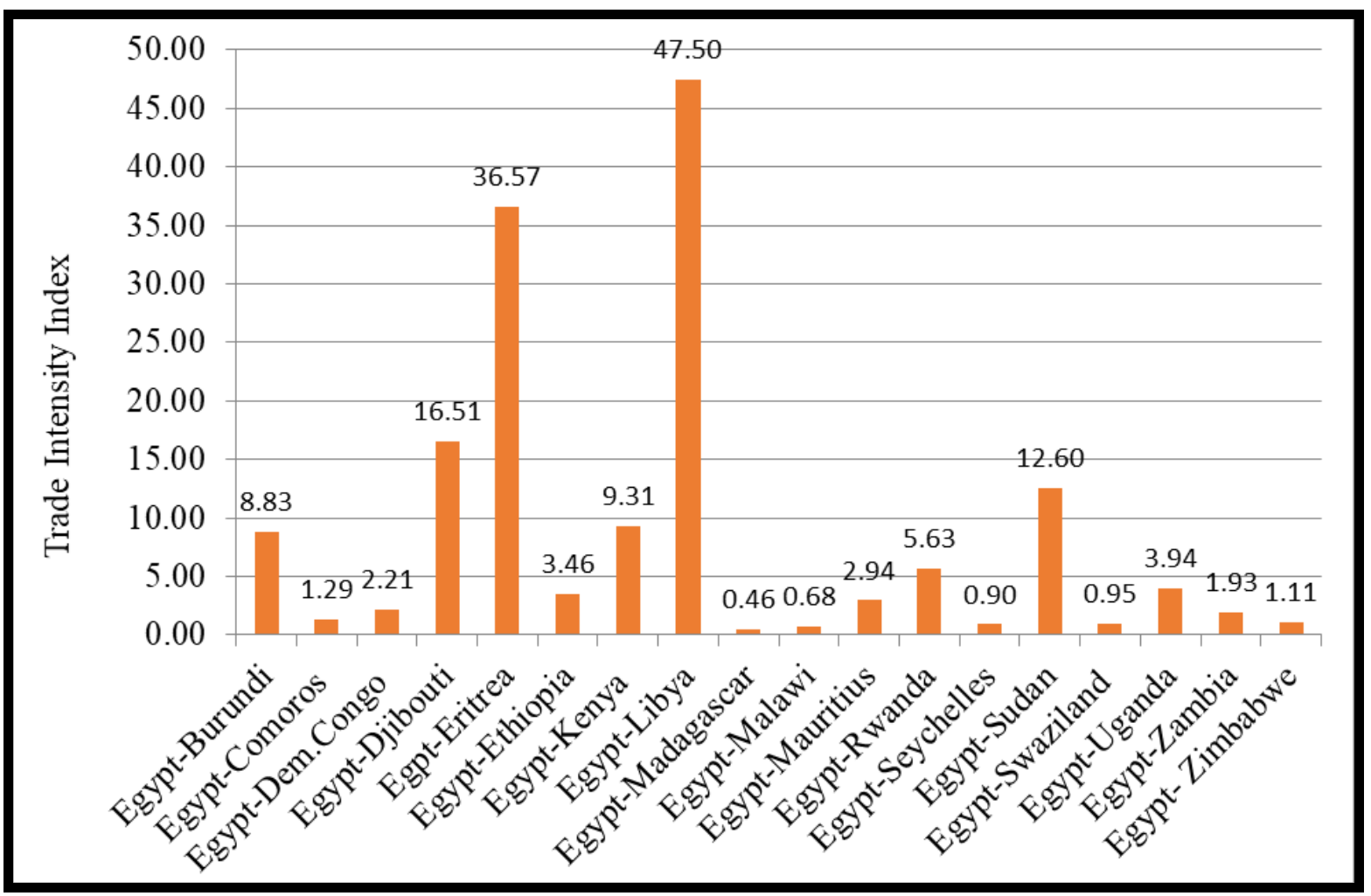

Source: Authors' estimates 
Eritrea's economic partners included Burundi, Comoros, Djibouti, Kenya, Rwanda, Sudan, and Zimbabwe, and their TII was more than unity. Djibouti and Sudan, with TIIs of 18.0 and 8.0, were the most important trading partners for Eritrea in terms of trade expansion. According to the natural trading partner theory, economies tend to trade more with their neighbors (Wonnacott and Lutz cited in Anurag Anand, 2016).Therefore, because of their geographical proximity, as well as cultural and economic links most of the member countries trade with each other than distant world. In the same manner, when we look at the trade intensity index of Ethiopia with Comoros, Djibouti, Egypt, Kenya, Libya, Sudan, and Swaziland, is above one with different magnitude. Djibouti and Sudan are the two countries with whom Ethiopia got high trade intensity.

Kenya, unlike other COMESA members, has exhibited an increasing tendency to deal intensively with geographically distant COMESA trading partners of varying magnitude (see Figure 7). Kenya and others have higher trade intensity indexes than Unity, with the exception of Libya, Madagascar, Swaziland, and Zimbabwe. Kenya mostly increased trade with neighboring countries such as Burundi, Uganda, Rwanda, and the Democratic Republic of the Congo (DRC), with TIIs of 38.0, 50.9, 36.3, and 13.1 correspondingly. This shows that Kenya has significant trade potential to expand and benefit from additional regional trade possibilities in order to promote its economic growth and development.

Figure 7: Trade intensity index between Kenya and other members of COMESA

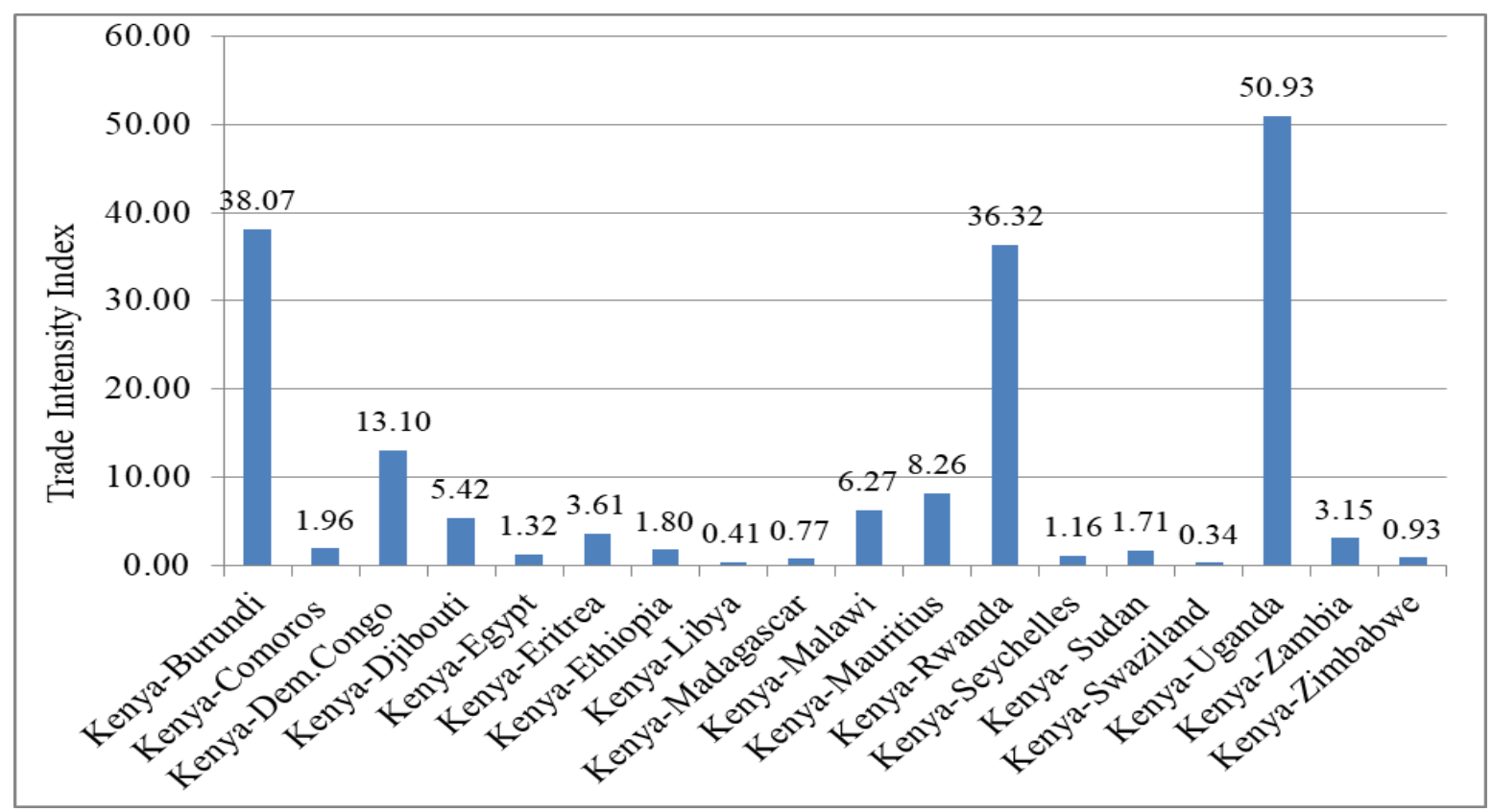


Source: Authors' estimates

According to the results for Libya, Sudan and Seychelles performed the worst in the region in terms of intratrade, with the majority of their bilateral TIIs showing less than unity with other countries of the group. The research of trade intensity between these nations and other COMESA members shows that they are not completely exploiting their regional trade potential. As a result, we may conclude that other COMESA countries are not extremely important trade partners for Libya, Sudan, and Seychelles when considering policy and economic decision-making units.

Figure 8 depicts the intra-COMESA trade intensity index at the regional level, which has fluctuated over time. This suggests that COMESA intra-regional commerce increased significantly between 2000 and 2003, and again between 2013 and 2016. The Intra Regional Trade Intensity Index (IRTII) was over eight from 2000 to 2016, peaking at 14.24 in 2003 and 13.59 in 2016. In comparison, the IRTII was 7.33, 7.85, and 7.99 in 2008, 2009 , and 2010, all of which were below eight.

Figure 8: Regional trade intensity index of COMESA

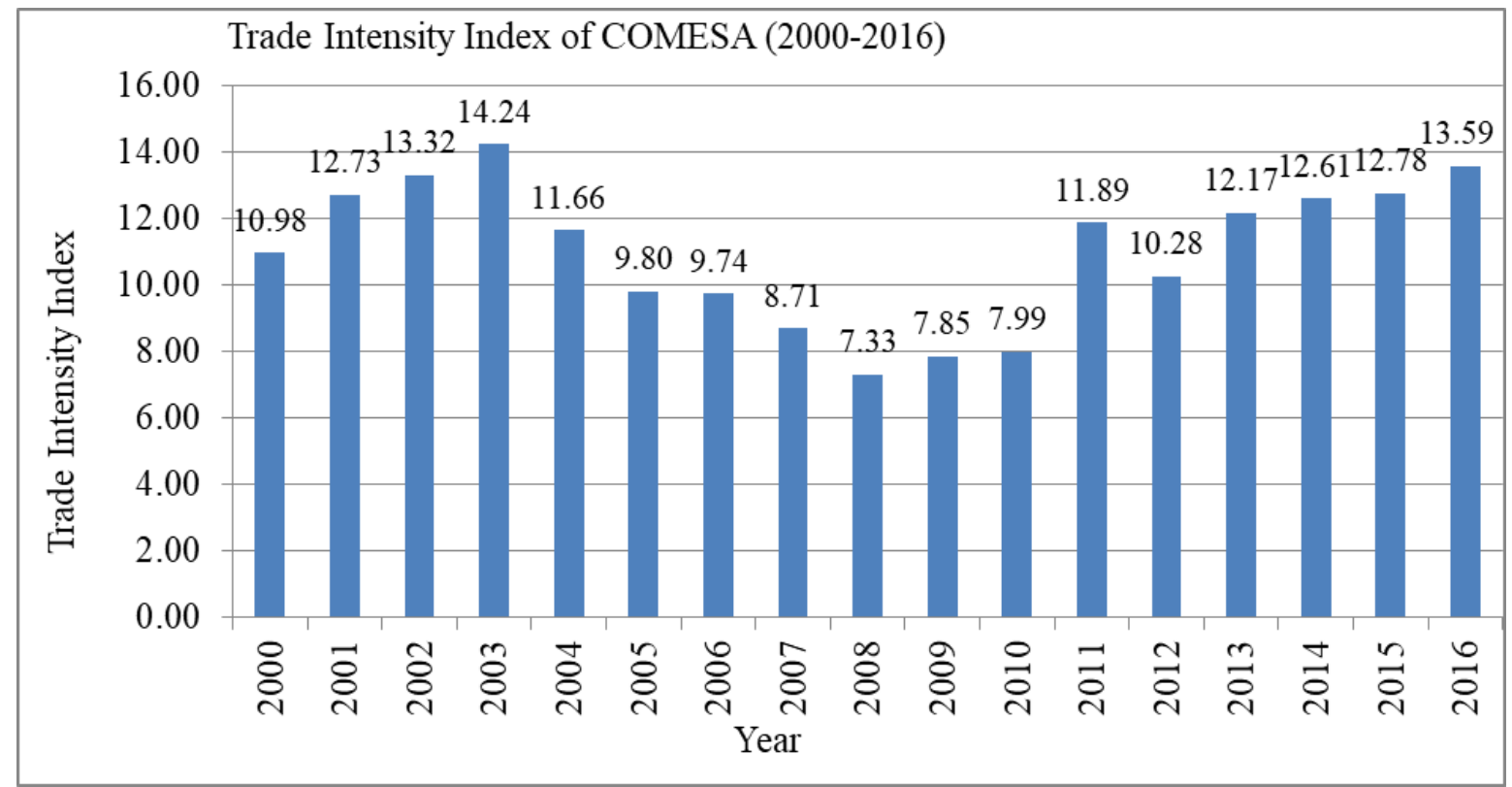

Source: Author`s computation based on IMF trade data. 


\section{SUMMARY, CONCLUSION AND RECOMMENDATIONS}

Based on the data analyzed in the preceding chapter, this chapter gives a summary of the study and its conclusions, as well as some policy implications, recommendations, and opportunities for further research.

\subsection{Summary of findings and conclusion}

COMESA's goal is to improve economic and social links among member nations by boosting intra-trade. Despite the fact that intra-trade volumes among members are low (mostly primary products) in comparison to other regional blocks, intra-trade has been conducted in various quantities among most of the members since the formation of the regional trade agreement. Using trade intensity, this study looked at the factors of intraregional trade dynamism within COMESA members from 2000 to 2016.

The study employed the augmented gravity model approach to uncover factors affecting intra-regional trade in COMESA member states and used the trade intensity index to estimate each COMESA member state's export share. The intra-export-COMESA trade intensity index, which remained at 13.6 in 2016, suggested that intra-export-COMESA trade remains low. According to the study, between 2000 and 2016, the share of intraCOMESA exports averaged 11 percent. From 2000 to 2003, and again from 2013 to 2016, COMESA intraexport-regional commerce increased dramatically. Intra-regional trade intensity increased from 2000 to 2016, reaching 14.24 in 2003 and 13.59 in 2016. In 2008, 2009, and 2010, it was less than eight, at 7.33, 7.85, and 7.99 , respectively.

Egypt and Kenya had the largest share, while Libya, Sudan, and Seychelles had the lowest intra-trade performance in the region, with the majority of their bilateral TII showing less than unity with other countries of the group. The research of trade intensity between these nations and other COMESA members shows that they are not completely exploiting their regional trade potential. As a result of the findings, we may conclude that other COMESA countries are not very important trade partners for Libya, Sudan, and Seychelles in terms of policy and economic decision-making.

In contrary to other members of COMESA, Egypt and Kenya have shown an increasing tendency to trade intensively with geographically distant trading partners in COMESA with different magnitude in which their TII were greater than unity. This indicates that both countries have strong trade potential to expand and benefit more trade opportunities from the region to boost its economic growth and development.

Generally, most of the COMESA members are trading more with their neighbor than distant members because of geographical proximity, as well as cultural and economic links. This suggests that there may be 
other factors such as transport costs, logistical impediments, poor infrastructural development and lack of trade complementarities that made most members to trade with nearby countries. This shows most of the countries prefer to trade more with the bordering partner countries to decrease the cost of transportation of goods and services associated with the distance between the members in the region. This goes mainly with the natural trading partner location and transport cost hypothesis of Wonnacott and Lutz (1989) suggesting that geographical proximity between countries tends to increase trade between them and reduce trade diversion.

Generally, it can be concluded that the regional trade integration among COMESA was not as satisfactory as expected and the intra-export volume is limited among members. In 2016 the export trade intensity of the region stood at 13.6 percent. This indicates more than 80 percent of the region`s export trade has been performed with the rest of the world. The poor performance of trade might be associated with some of trade barriers like poor infrastructure, low commitment to regional integration, overlapping memberships, lack of institutional democratic election, low inward flows of FDI, lack of complementarities of products (most of them have similar export profiles), small and fragmented economies with low incomes, low percapita-income, lack of access to seaport for some members, unequal distribution of benefits among member countries after join the FTA of COMESA. Example Egypt and Kenya is the most beneficiary than other members. This problem arises because the more developed members benefit more than the less developed ones, whilst there are mostly no compensation mechanisms to help the losers.

In line with this, Yang and Gupta (2005) also summarized the general unsuccessfulness reasons of Africa in promoting intra-trade and foreign direct investment due to high external trade barriers and low resource complementarity between member countries limit both intra- and extra regional trade. Small market size, poor transport facilities and high trading costs also make it difficult for African countries to reap the potential benefits of RTAs. To increase regional trade and investment, African countries need to undertake more broadbased liberalization and streamline existing RTAs, supported by improvements in infrastructure and trade facilitation.

\subsection{Recommendations}

The research study finds that the economic size and income per capita or population size variables are positively related to the level of trade. These variables determine the purchasing ability of the members. But most of the members are economically categorized within the low level of income which constraints the intratrade capacity among them. In relation to international terms COMESA is characterized by small GDP of 
$\$ 754$ billion. Egypt only accounts for 44 per cent of COMESA's GDP which indirectly shows almost all COMESA countries can be classified within small, low-income countries. Because of this the potential trade expansion among members is regarded as low. Therefore, it is recommended for the member states to increase their income through spending on pro-poor areas like health, education, and increasing of consumption, public and private investment. Moreover, COMESA member states need to maintain a high and sustainable economic growth.

Regional economic integration is aimed to boost the economy of each member state through diversification of comparative advantages by exploiting the available opportunities. But most of the COMESA members are characterized by similar export profiles with labor intensive (primary commodities) and low technological involvement. A study of product complementarity indices for COMESA bilateral trade among members indicate that product complementarities between exports of Egypt and imports of the other member countries average to 43.0 while those for Kenya's exports to the region average to 38.6. For all other countries, the average product complementarity for exports is far lower and arrangements with a value of less than 25 have failed (Tsikata, cited in Khandelwal, 2004).

Therefore, to ensure the expansion of market it is recommended that each member state needs to produce complementary products (export diversification) where they have a revealed comparative advantage through identification of priority products that exist in the region. This could encourage market expansion in the region as well as supporting domestic industries in the specific states. It also helps to reduce unemployment and the risk of getting to global economic shocks. Furthermore, each member state needs to create an enabling environment for private sectors that play a crucial role in structural diversification by developing new products, new markets, and new ways of doing business to enhance intra-COMESA trade.

In support of this, AfDB (2011) recommended that specific policy actions should be directed at correcting to promote intra-regional trade and economic integration. Like the oil-rich Middle East countries have successfully done, resource-rich African countries should invest their resource rents in strengthening agriculture and manufacturing. Infrastructure development should be a major policy focus. Emphasis should be shifted from raw material exports to moving up the value chain by exporting semi-processed products with the aim of gradually moving to fully processed products based on the available raw products. For instance, Ethiopia and DRC Congo should consider establishing a major production firm given their wealth in Coffee and different mineral production respectively. 
Therefore, to increase the intra-African trade and resolve the challenges of overlapping memberships the study recommend the practical implementation of Continental Free Trade Area (CFTA) declaration of AU Assembly of Heads of State and Government, in 2012, which is also intended to establish a single continental market for goods and services, free movement of business persons and investments, expand intra-African trade and increase the continents appeal as a global trade partner.

In general, this study has examined the determinants of intra-regional trade within COMSA from 2000 to 2016 using dynamic panel data and augmented gravity model. The study also investigated trade intensity index among members. The study found out that FTA has positive significant impact on export trade. With trade intensity index most, the members have weak bilateral trade relationship except Egypt and Kenya. Generally, I recommend for more detail future research to study on factors that lead the ineffective performance of COMESA regional trade agreement with other intra-trade policy variables at aggregate and disaggregate level to identify determinants of COMESA intra-trade.

\section{REFERENCES}

Abidin, I., Bakar, N., and Sahlan, R. (2013). The determinants of exports between Malaysia and the OIC member countries: A gravity model Approach. Procedia Economics and Finance 5 (2013) 12 - 19. Available online at www.sciencedirect.com.

AfDB, OECD, \& UNDP (2017). African Economic outlook. Trade policies and regional integration in Africa. Chapter three p.74-95. www.africaneconomicoutlook.org.

African Development Bank (2011). Trade and economic integration in Africa: Trend, pattern and future outlook. https://www.afdb.org/

African Development Bank (2000). Regional Integration in Africa, African Development Report 2000, (Oxford: Oxford University Press).

African Development Bank Group (2013). Understanding the Barriers to Regional Trade Integration in Africa. NEPAD, Regional Integration \& Trade Department Report. Retrieved from www.afdb.org

Ahmad, A., (2014). Essays on trade integration among GCC Countries; University of Southampton, school of social sciences, department of economics.

Al-Atrash, H, \& Yousef, T., (2000). Intra-Arab trade: Is it too Little? Working Paper WP/00/10. Middle Eastern Department, International Monetary Fund.

Albert, M., (2012). Impacts of regional trade agreements on trade in Agri-food products: Evidence from Eastern and Southern Africa, paper submitted to African economic conference, USAID Southern Africa trade hub, Botswana. 
Alemayehu, G. and Haile, K., (2008). Regional Economic Integration in Africa: A Review of problems and prospects with a case study of COMESA. Journal of African Economies, Volume 17, Issue 3, 1 June 2008, Pages 357-394,https://doi.org/10.1093/jae/ejm021

Aliyu, Sh., and Bawa, S., (2015). Gravity model by panel data approach: Empirical evidence from Nigeria. Article in International Journal of Trade and Global Markets 8(1), DOI: 10.1504/IJTGM.2015.067972

Amir, R. and Ahmad, T. (2012). Gravity model: An application to trade between Iran and Regional blocs, Iranian economic review, Vol.16, No.31, winter 2012.

Amoah, G., (2014). Intra-African Trade: Issues involved in improving Ghana's trade with the rest of Africa. ISSN 2224-607X (Paper) ISSN 2225-0565 (Online) Vol.4, No.2, 2014. Retrieved from

Anand, A., and Garg, K., (2016). A Study of India's Trade Intensity with United Arab Emirates: An Overview. International Journal of Electrical, Electronics and Computers (EEC Journal) Vol-1, Issue-1, MayJune- 2016.

Anderson, J. \& Van Wincoop, E. (2004). Trade costs, Journal of Economic Literature, Vol. 42, No. 3.pp. 691751, American Economic Association.

Anderson, J., (2016). The Gravity Model of Economic Interaction. Boston College and NBER . https://www2.bc.edu/james-anderson/GravityModel.pdf

Anurag Anand, K., (2016). A Study of India's Trade Intensity with United Arab Emirates: An Overview. International Journal of Electrical, Electronics and Computers (EEC Journal) [Vol-1, Issue-1, MayJune- 2016].

Assefa, M., (2014). COMESA's trading with China: Patterns and prospects. International journal of African development v.1 n.2 spring 2014. http://scholarworks.wmich.edu/ijad.

African Union Commission (2015). Agenda 2063. The Africa We want. Final edition, Addis Ababa, Ethiopia.

AU and ECA (2012). Boosting Intra-African Trade. Issues Affecting Intra-African Trade, Proposed Action Plan for boosting Intra-African Trade and Framework for the fast tracking of a Continental Free Trade Area.

AU, AfDB, and UNECA (2016). Africa regional integration index report. Find out more on www.integrate africa.org.

Augustin, N., and Regina, T., (2011). Research in business and economics journal, the determinants of trade in the central African economic and monetary union, Bowie State

Awad, T., Sawkut, R., Mehra, M., \& Pant, M. (2008). Regional trade integrations: A comparative study the cases of GAFTA, COMESA, and SAPTASAFTA. United Nations Conference on Trade and Development Virtual Institute Research Material.

Baier, S., and Bergstrand, J., (2001). The growth of world trade: tariffs, transport costs, and income similarity, Journal of International Economics, 53, 1-27.

Baier, S., and Bergstrand, J., (2004). Economic determinants of free trade agreements. journal of international economics, 64(1), 29-63.

Baier, S., and Bergstrand, J., (2009). Estimating the effects of free trade agreements on international trade flows using matching econometrics. Journal of International Economics, 77(1), 63-76.

Balassa, B., \& Bauwens, L., (1987). Intra-industry specialization in a multi-country and multi-industry framework. Economic journal, 97, 923-939.

Bamou, E., and Tchanou, J. (2006). Trade and investment policy reforms in Cameroon: impact assessment and perspectives. University of Yaoundé II, Faculty of Economics and Management.

Bénassy-Quéré, A., and Lahrèche-Révil, A., (2003). Trade linkages and exchange rates in Asia: the role of China. CEPII Working Paper, 2003-21.

Bhagwati, J., \& Panagariya, A., (1996). The economics of preferential trade agreements. The AEI Press Publisher for the American Enterprise Institute Washington, D.C. Center for International Economics University of Maryland College Park. 
Bhagwati, J., Greenaway, D., and Panagariya, A., (1998). Trading preferentially: Theory and policy, the economic journal, vol. 108, No. 449, pp.1128-1148.

Bikker, J., (1987). An international trade flows model with substitution: An extension of the gravity model. Kyklos, 40(3), 315 - 337.

Brookings African growth initiatives (2012). Accelerating growth through improved intra-African trade.

Boniface, O., and Manaseh O., (2017). Key issues in regional integration vol.5. An annual publication of COMESA Secretariat, Lusaka, Zambia.

Carim, X., (1997). Multilateral trading, regional integration and the Southern African Development Community. The South African Journal of Economics, 65 (3): 334-353.

Cassim, R., (2001). The determinants of intra-regional trade in Southern Africa with specific reference to South Africa and the rest of the region. DPRU Working Paper 01/51. University of Cape Town.

Chen, Ch., (2014). The dynamics of privatization in China (1994-2008): An empirical and econometric analysis. PhD thesis department of economics, school of Oriental and African studies, university of London. Retrieved from http://eprints.soas.ac.uk/18444/1/Chen_3593.pdf.

Clark, P., Tamirisa, N., Wei, S., Sadikov, A., \& Zeng, L., (2004). Exchange rate volatility and trade flowssome new evidence. IMF Occasional Paper, 235.

COMESA (2013). International trade statistics bulletin No. 12, division of trade, customs and monetary affairs COMESA secretariat Lusaka, Zambia.

David J.and Zainal Y., (2003). Developing indicators of ASEAN integration. A preliminary survey for a roadmap. REPSF Project 02/001.

Deardorff, V., and Stern. R., (1994). Multilateral Trade Negotiations and Preferential Trading Arrangements, in Alan V. Deardorff and Robert M. Stern, eds., Analytical and Negotiating Issues in the Global Trading System. Ann Arbor: University of Michigan Press, 1994, 27-85..

Edmonds, CH., and Li, Y., (n.a). A new perspective on China trade growth: Application of a new index of bilateral trade intensity. Available at http://www.economics.hawaii.edu/research/workingpapers/WP_10-25.pdf

Ekanayake, E., and Ledgerwood, J., (2009). An analysis of the intra-regional trade in the Middle East and North Africa region. The International Journal of Business and Finance Research Volume 3 Number 1 .

Elbushra. A., Karim, I. and Suleiman, I., (2011). The role of COMESA in promoting intra-regional agricultural trade: Case study of Sudan. Journal of the Saudi society of agricultural sciences, (2011)10, 59-64. 62-64.

Elmorsy, S., (2015). Determinants of trade intensity of Egypt with COMESA Countries. Journal of the Global South (2015) 2:5 DOI 10.1186/s40728-014-0002-6.

Elmorsy, B., (2015). Determinants of trade intensity of Egypt with COMESA Countries. Journal of the global south (2015) 2:5 DOI 10.1186/s40728-014-0002-6.

Etale, E., \& Etale, L., (2016). The Relationship between exports, foreign direct investment and economic growth in Malaysia. International journal of business management and economic research (IJBMER), Vol 7(2),2016, 572-578.

Geda, A. and Seid, E. (2015). The potential for internal trade and regional integration in Africa. Journal of African Trade 2 (2015) 19-50. Available online at www.sciencedirect.com.

Geda,A., and Kibret, H., (2002). Regional economic integration in Africa: A review of problems and prospects with a case study of COMESA. Journal of African economies, June 2008, volume 17, issue 3. DOI: $10.1093 /$ jae/ejm021.

George, O., and Ansah, A., (2014). Intra-African trade: Issues involved in improving Ghana's trade with the rest of Africa, ISSN 2224-607X (Paper) ISSN 2225-0565 (Online) Vol.4, No.2, 2014.

Hamanaka, S., (2013). Cross-Regional Comparison of Trade Integration: The Case of Services, Asian Development Bank Working Paper Series on Regional Economic Integration, No. 108. 
Helpman, E., \& Krugman, P., (1985). Market structure and foreign trade: Increasing returns, imperfect competition and the international economy: MIT Press, Cambridge.

Helpman, E., \& Krugman, P., (1989). Trade policy and market structure. Cambridge: Mass: MIT Press.

Helpmen, E., (1975). Intra-Industry Trade: The theory and measurement of international trade in differentiated products. Journal of international economics, 11(3), 305-340.

Helpman, E., Melitz, M. and Rubinstein, Y., (2008). Trading partners and trade volumes, Quarterly Journal of Economics 123: 441-87.

Iringo, E., (2005). Regional economic integration: The challenge of dual membership to Kenya- with special reference to EAC and COMESA. University of Nairobi.

Jelena, T., and Lukasz, K., (2015). The determinants of intra-regional trade in the Western Balkans, Zb. rad. Ekon. fak. Rij. 2015 vol. 33.

Jordaan, A., (2014). The impact of trade facilitation factors on South Africa's exports to a selection of African countries. URI: http://hdl.handle.net/2263/42655

Jung, T., and Jin, Y., (2005). Free trade agreements in East Asian countries: What has been done and what needs to be done? Journal of international economic studies vol. 9, No. 1.

Karamuriro, H., (2015). Determinants of Uganda's Export Performance: A Gravity Model Analysis. International Journal of Business and Economics Research. Vol. 4, No. 2, 2015, pp. 45-54.

Kenani, M., (2014). Impact of FDI Inflows, trade openness and inflation on the manufacturing export performance of Tanzania: An econometric study. International journal of academic research in economics and management sciences vol. 3, No. 5 ISSN: 2226-3624.

Korinek, J., and Melatos, M., (2009). Trade Impacts of selected regional trade agreements in agriculture, OECD trade policy working papers, No. 87, OECD publishing, doi:10.1787/225010121752.

Krugman, P., (1980). Scale economies, product differentiation and the pattern of trade, American Economic Review 70: 950-9.

Laura, M., (2007). New determinants of bilateral trade: An Empirical analysis for developed and developing countries, Universitat Jaume. I.

Lee, Ch., (2002). Korea's FDI Outflows: Choice of Locations and Effect on Trade, KIEP Working paper 0207, KIEP.

Lee, J., Park, I., and Shin, K., (2008). Proliferating Regional Trade Arrangements: Why and Whither? https://doi.org/10.1111/j.1467-9701.2008.01143.x

Linneman, H., (1966) An Econometric Model of International trade flows. Amsterdam: North Holland Publishing Co.

Mary A., Dyana N., and Won K., (2002). International Trade and Foreign Direct Investment: Substitutes or Complements. Journal of Agricultural and Applied economics, 34.2(August 2002):289-302, Southern Agricultural Economics Association.

Mengesha, N., (2009). Trade Effects of Regional Economic Integration in Africa: The Case of SADC (Evidence from Gravity Modeling Using Disaggregated Data). Trade and Industrial Strategy. Thematic Working Group Paper. Retrieved from http://www.tips.org.za/.

Mold, A., and Mukwaya, R., (2016). Modeling the economic impact of the tripartite free trade area: Its implications for the economic geography of Southern, Eastern and Northern Africa. Journal of African Trade Volume 3, Issues 1-2, Pages 57-84

Moser, P., (1997). Reasons for regional integration agreements, Intereconomics, ISSN 0020-5346, Nomos Verlagsgesellschaft, Baden-Baden, Vol. 32, Iss. $\quad 5, \quad$ pp. 225-229, http://dx.doi.org/10.1007/BF02929831.

Murinde, V., (2001). The Free Trade Area of the Common Market for Eastern and Southern Africa. England: Ashgate.

Musila , J., (2005). The intensity of trade creation and trade diversion in COMESA, ECCAS and ECOWAS: A comparative Analysis. Journal of African Economies, 2005, vol. 14, issue 1, 117-141. 
Olaniyan R., (2008). Challenges in achieving regional integration in Africa. A keynote address at the southern Africa development forum on progress and prospects in the implementation of protocols in southern Africa organized by UNECA-SA Lusaka, Zambia.

Ouma, D., (2016). Trade agreement and agricultural trade in East African Community. African Journal of Economic Review, Volume IV, Issue 2.

Pitigala, N., (2005). What does regional trade in South Asia reveal about future trade integration? Some Empirical Evidence. World Bank policy research working paper 3497.

Sako, S., (2006). Challenges facing Africa's regional economic communities in capacity building. ACBF occasional papers, no. 5. Harare: ACBF.

Santos, S., and Tenreyro, S., (2009). Further Simulation Evidence on the Performance of the poisson pseudo-maximum likelihood estimator. Center for Economic Performance (CEP) discussion paper No 933.The London school of economics and political science.

Schiff, M., and Winters, L., (2003), Regional integration and development. The World Bank, Washington, DC. 20433.

Souad, M., Mohamed, S. and Kamel, F., (2015). An Empirical assessment of Intra-regional trade relationships: The GCC context. University of Sharjah journal of international Refereed periodical of Humanities and Social Sciences. Vol. 12, No. 1 Sha'ban 1436 H. / June 2015 AD. ISSN: 19962339.

Tafirenyika, M., (2014). Intra-Africa trade: Going beyond political commitments. From Africa Renewal. Available at https://www.un.org/africarenewal/magazine

Teunissen, J., (ed.) (2005). Africa in the World economy: The national, regional and international challenges. Fondad, The Hague.

Tinbergen, J., (1962). Shaping the World Economy, Twentieth Century Fund.

Tomasziw, I.,and Kirkpatrick,C.,(2009). Trade facilitation and manufactured exports: Is Africa different? World Development, 37(6), 1039-1050.

Umurungi, F. (2005). A critical overview of regional trade integration: lessons for COMESA. Faculty of economics and management sciences, University of the Western Cape, South Africa.

UNCTAD and WTO secretariats (n.a). A practical guide to trade policy analysis. Retrieved from https://www.wto.org/english/res_e/publications_e/wto_unctad12_e.pdf

UNCTAD (2006). Trade capacity development for Africa: Trade negotiations and Africa series: no. 3, policy issues for African countries in multilateral and regional trade negotiations. New York and Geneva.

UNECA (2017). COMESA Trade and Market Integration. Retrieved from http://www.uneca.org

UNECA (2016). Tripartite intra-regional trade Agreement. Retrieved from http://www.uneca.org

UNECA, AU and AfDB (2017). Assessing Regional Integration in Africa VIII: Bringing the Continental Free Trade Area About. Addis Ababa, Ethiopia.

Urata, S., and Okabe, M., (2007). The impacts of free trade agreements on trade flows: An application of the gravity model approach. RIETI discussion paper Series 07-E -052 revised. 